\title{
Summary of Fiscal Year 1994 Near-Infrared Spectroscopy Moisture Sensing Activities
}

\author{
F. R. Reich \\ R. E. Johnson \\ B. L. Philipp \\ J. B. Duncan \\ G. L. Schutzenhofer
}

Date Published

January 1995

Prepared for the U.S. Department of Energy

Office of Environmental Restoration and

Waste Management

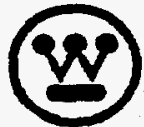

Henford Operations and Engineering Contractor for the

U.S. Department of Eneroy under Contract DE-AC06-87RL10930

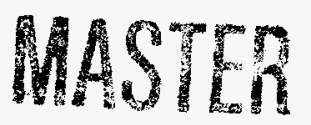

Approved for Public Release 


\title{
RELEASE AUTHORIZATION
}

Document

Number:

Document Title:

Release Date:
WHC-EP-0839

Summary of Fiscal Year 1994 Near-Infrared Spectroscopy Moisture Sensing Activities

This document was reviewed following the procedures described in WHC-CM-3-4 and is:

\section{APPROVED FOR PUBLIC RELEASE}

WHC Information Release Administration Specialist:

\author{
M.N. Boston
}




\section{DISCLAIMER}

This report was prepared as an account of work sponsored by an agency of the United States Government. Neither the United States Government nor any agency thereof, nor any of their employees, make any warranty, express or implied, or assumes any legal liability or responsibility for the accuracy, completeness, or usefulness of any information, apparatus, product, or process disclosed, or represents that its use would not infringe privately owned rights. Reference herein to any specific commercial product, process, or service by trade name, trademark, manufacturer, or otherwise does not necessarily constitute or imply its endorsement, recommendation, or favoring by the United States Government or any agency thereof. The views and opinions of authors expressed herein do not necessarily state or reflect those of the United States Government or any agency thereof. 


\section{DISCLAIMER}

Portions of this document may be illegible in electronic image products. Images are produced from the best available original document. 


\section{EXECUTIVE SUMMARY}

An infrared spectroscopy-based technique. with remote fiber optic probes. is being developed for the in situ measurement of moisture in high-level tank wastes. The strong infrared absorption of water provides a sensitive technique to sense the water content of high-level waste materials for both ex situ (measurements on extruded tank cores) and in situ tank applications. Development of this technique was jointly supported by the U.S. Department of Energy's EM-50 Office of Technology Development Support and EM-30 Tank Waste Safety and Tank Waste Remediation Systems Programs.

Low moisture has been identified as one of the critical parameters in the safety status of the Hanford Site's underground storage tanks containing organics and ferro/ferricyanide materials. The target accuracies needed for waste tanks indicated that \pm 5 wt\% accuracy was needed with wastes having 5 - to 30 -wt\% moisture while \pm 10 wt\% accuracy was needed from 31 - to 70 -wt\% moisture.

The basis for the near-infrared (NIR) moisture sensing technology stems from feasibility work performed by the Center for Process Analytical Chemistry (CPAC) with waste tank simulant materials. The CPAC work showed that the NIR region could provide moisture prediction with errors in the range of 0.5 to 1.5 wt\% for BY-104 simulants with 0 - to 25 -wt\% moisture content. Further studies showed that particle size and chemical content distributions would have only a minimum impact on the moisture sensing performance.

An NIR spectroscopy system with a remote fiber optic probe was obtained from the Savannah River Laboratory (SRL) that uses the 1.4- to 1.5- $\mu \mathrm{m}$ water absorption band (an overtone band) to sense moisture content. The moisture reading is derived from the NIR spectra with a partial-least-squares (PLS) calibration model that is built with spectra from standard moisture samples. This NIR system is a compact. rugged design that allows it to be transported with little effect on the system's performance.

The NIR system was evaluated with moisture standards prepared from four waste tank simulants that are representative of a partial range of real tank wastes. These simulants have unique physical and chemical properties that impact their responses to moisture. The moisture ranges of the samples used in this testing were as follows: 
- 101-SY, 5 to $25 \mathrm{wt \%}$ (complexed waste simulant containing organics)

- BY-104. 0 to $25 \mathrm{wt \%}$ (saltcake simulant)

- T Plant Bottom. 5 to 40 wt\% (ferrocyanide tank sludge/slurry)

- T Plant Top. 10 to 60 wt\% (upper ferrocyanide tank sludge/slurry).

Samples were prepared by grinding dried simulant and then adding water to achieve target weight-percent levels.

All simulants were optically dark (which suggests high optical absorption) with some color variations between different simulants. All samples became darker with increased water content. Since there is little likelihood that the water caused chemical variations, these optical changes suggest that the current hot cell technique of using visual inspection to determine sampling may be falsely biased.

With some of the drier samples, it was necessary to have several cubic centimeters of sample to ensure that light was not being lost by the sample and that room light was not penetrating an optically thin sample. This indicates that the volume sampled by the NIR moisture probe is more than several micrometers in thickness.

The SRL NIR system acquired spectral data over the range from 1100 to $1700 \mathrm{~nm}$. but the usable spectral range was truncated to eliminate noise and to concentrate modeling on the most active region of this water absorption band. After model testing indicated that the PLS calibration models out-performed models constructed using principal component regression techniques. the PLS models were then used to complete cold calibration test/evaluations. Spectral smoothing and preprocessing were used to improve the calibration performance.

In general. the best overall moisture predicting performance was produced by a 20-coefficient model using smoothed spectral data and first or second derivative preprocessing. By observation of data clustering in Figure ES-1. the second derivative model performs better in the lower moisture ranges that are the region of highest concern with tank material. Figure ES-1 shows that the errors of prediction from the second derivative all fall with in an envelope of $\pm 5 \mathrm{wt} \%$. This "total error" band is comparable to a \pm 3 sigma confidence level.

To provide some indication of the performance with "unknown" samples. calibration models were constructed leaving out selected simulant data sets. The omitted data sets were then used as "unknowns" to evaluate the performance of the 
20 factor PLS model

with 2 nd derivative pre-processing

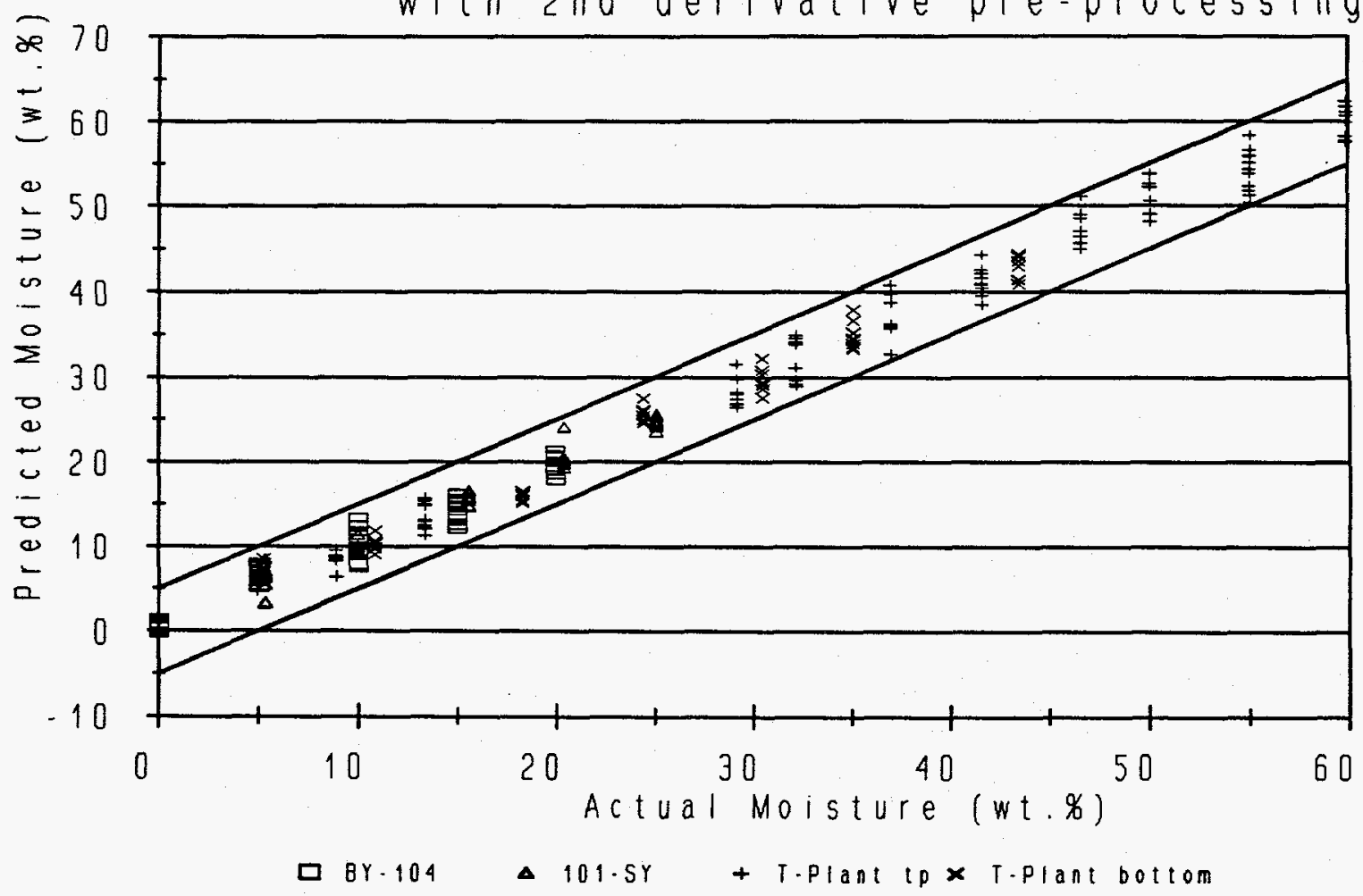

Figure ES-1 Twenty-Factor Partial-Least-Squares Mode1 with Second Derivative Preprocessing

calibration model.

Two types of "unknown sample" testing were completed: moisture sample omission (modeling without a selected moisture sample) and tank simulant omission (modeling without a selected tank sample). From these omission tests it was found that the more chemically similar an unknown sample is to the chemistry of the samples used to make the calibration model. the better the model predicts the unknown samples' moisture content. It was also found that the standards used to construct the calibration models must include the whole range of moisture levels over which the model will be used.

\section{CONCLUSIONS}

An NIR spectroscopy system, developed by SRL for hot cell applications. has been successfully tested and demonstrated with tank simulant materials for remote moisture measurement applications. The cold tests and demonstrations show that NIR 
spectroscopy with PLS calibration models is viable with waste tank types of materials that have a high caustic level and a variable molecular content. Further testing with real tank waste material is need to verify that the technique is transferable to real tank materials.

The results of this testing with moisture standards indicate a capability to sense moisture with an root-mean-square error of less than \pm 2 wt\% over a moisture range of 0 to $60 \mathrm{wt} \%$. Over this same moisture range, the error for all predicted moisture levels from all samples fell within a \pm 5 wt\% error range (total error band). These results successfully meet the requirements needed to quantify the moisture of ferrocyanide and organics-bearing tank waste materials.

The following issues and further work need to be addressed by this project:

1. A hot cell test campaign with real waste tank materials is needed to validate the NIR moisture response and the potential for using cold calibration models with major tank material chemicals.

- Cold test/analysis with NIR and Raman systems has shown that there are significant chemical and physical differences between simulant and real waste materials. The impact on moisture sensing is not known at this time.

2. The SRL NIR system hardware as it currently exists is not suitable for routine hot cell core scanning applications. This is not a basic technology issue, but a systems engineering issue. The existing system's hardware would be usable in a hot cell demonstration to acquire data that could be processed with offline software when "real-time" moisture data is not needed. For online data acquisition. improvements are needed.

- The SRL model's software cannot handle the large number of calibration samples that will be required for more routine hot cell use.

- Software readiness and potential errors are unresolved issues/problems with the current SRL system/hardware. 
3. Cold testing is needed to verify the performance of a commercial NIR system purchased in fiscal year 1994 as a replacement for the SRL systems.

- Calibration model software needs to be developed and integrated into the NIR moisture sensing system: the software needs to handle the large calibration data set. provide "real-time" moisture readout. and include multiple calibration programs to extract the "best" estimate of moisture from a tank sample.

- Total moisture sensing system packaging is needed that can handle the hot cell environment and the current mode of system operation around a hot cell.

4. Additional development work is needed for a routine hot cell moisture sensing system.

- A method for probe cleaning. or disposable probe sheaths, and light shielding need to be identified and tested relative to the use of the fiber optic probe in a hot cell application.

- A commercial source of fiber optic probes needs to identified. Handling and materials testing are needed to ensure probe integrity with the chemical mixtures that will be encountered in tank materials and to ensure that the replacement epoxy and new method of window attachment will not fail during hot cell use. 
WHC-EP-0839

This page intentionally left blank. 


\section{CONTENTS}

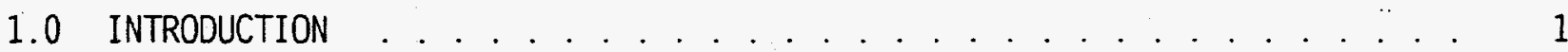

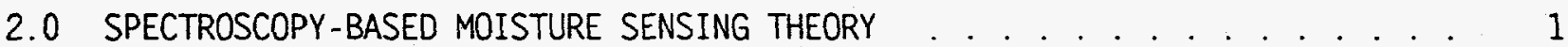

3.0 MOISTURE SENSING TECHNOLOGY DRIVERS AND GOALS . . . . . . . . . 2 3.1 SAFETY DRIVERS 3.2 DEPLOYMENT APPLICATION TARGETS $\ldots \ldots \ldots \ldots$

4.0 OPTICAL SPECTROSCOPY FEASIBILITY STUDIES . . . . . . . . 5

4.1 BASIC NEAR-INFRARED FEASIBILITY AND SENSITIVITY COMPARISON STUDY . . 5

4.2 PARTICLE AND IONIC CONCENTRATION INTERFERENCE STUDIES ...... 6

4.3 ATMOSPHERIC MOISTURE INTERFERENCE STUDIES . . . . . . . . . 6

4.4 MATERIAL IMPACTS ON SENSING VOLUME . . . . . . . . . . . . 7

5.0 DESCRIPTION OF THE SAVANNAH RIVER LABORATORY'S NEAR-INFRARED HOT CELL SYSTEM

5.1 ISSUES WITH THE SAVANNAH RIVER LABORATORY 'S NEAR-INFRARED SYSTEM $\cdots 9$

5.1.1 System Hardware and Software Documentation . . . . . . 9

5.1 .2 Hardware Issues . . . . . . . . 10

5.1.3 Combined Hardware and Software Issues ............... 10

6.0 TANK SIMULANT MOISTURE TEST SAMPLES AND MEASUREMENT PROCEDURES . . . . . 11

6.1 SAMPLE PREPARATION . . . . . . . . 12

6.2 SAVANAH RIVER LABORATORY'S NEAR-INFRARĖ SYSTEM SPËCTRUM $\ldots . . . .14$

6.3 TEST PROCEDURE

6.4 SAVANNAH RIVER LABORATORY 'S NEEAR-INFRARĖD MÓISTURE SAMPLE SPECTRAL
DATA SET

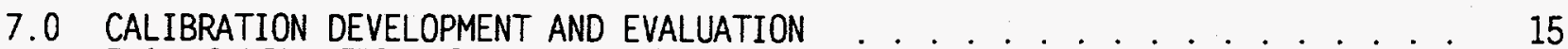

7.1 CALIBRATION MODELS: CONSTRUCTION AND TESTIING $\ldots \ldots \ldots \ldots$

7.1.1 Partial-Least-Squares Model Equation . . . . 16

7.1.2 Comparison of Principal-Component-Regression and PartialLeast-Squares Models ....... 16

7.2 WASTE TANK SIMULANT CALIBRATION MODEL ANALYSIS $\ldots \ldots \ldots$

7.2.1 Premodel Spectral Data Processing . . . . . . . . . 17

7.3 SINGLE SIMULANT MODELS . . . . . . . . . . . . . 18

7.4 MODEL PERFORMANCE FOR COMBINED SIMULANT DATA $\ldots \ldots \ldots$

7.5 UNKNOWN SAMPLE PERFORMANCE SIMULATION $\ldots \ldots$

7.5.1 Moisture Sample Omission Tests . . . . . . . . . . 22

7.5 .2 Tank Simulant Omission Tests ............. 23

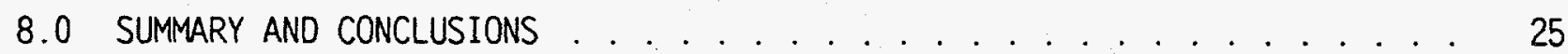

9.0 REFERENCES . . . . . . . . . . . . . . . . . . . . 28 
WHC-EP-0839

APPENDIXES

A FERROCYANIDE AND ORGANIC TANKS MOISTURE MEASUREMENT CRITERIA ...... A-1

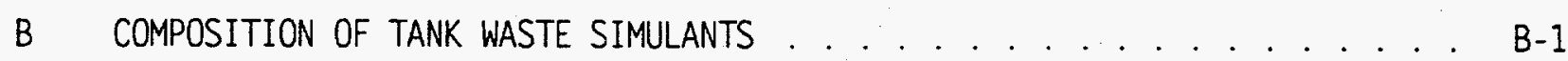




\section{LIST OF FIGURES}

1. Progressive Technology Development Diagram. . . . . . . . . . . . 1

2. Visible. Near-Infrared. and Mid-Infrared Composite Spectra from Center for Process Analytical Chemistry's Task 1 Work.

3. Hot Cell Near-Infrared System.

4. Photo of Samples Used During Testing of the Savannah River Laboratory's NearInfrared System.

5. Spectral Data Set Measured From ail Waste Tank Simulant Moisture Samples.

6. Comparison of PLS and PCR 10 factor calibration models from 101-SY simulant moisture samples with 2nd derivative pre-processing.

7. Comparison of First and Second Derivative Preprocessing with a 10 -Factor Partial-Least-Squares Model Built from BY-104 Moisture Samples.

8. Twenty-Factor Partial-Least-Squares Model with Mean-Centered Preprocessing. 20

9. Twenty-Factor Partial-Least-Squares Model with First Derivative Preprocessing 20

10. Twenty-Factor Partial-Least-Squares Model with Second Derivative Preprocessing1

11a. Root-Mean-Square Error of Moisture Prediction of a 11 Tank Simulants for Partial-Least-Squares Model Data in Table 3.

11b. 100 Percent Moisture Prediction Error Band for Partial-Least-Squares Models

12. Partial-Least-Squares Model Predicting Moisture of the BY-104 10-wt\% Sample. 23

13. Partial-Least-Squares Model Predicting Moisture of the T Plant Bottom 30-wt\% Sample.

14. Partial-Least-Squares Model Predicting 50- to 65-wt\% T PI ant Top Samples.

15. Twenty-Factor Partial-Least-Squares. Second Derivative Model Predicting all $T$ Plant Bottom Samples (5-. 11-. 18.3-.25-.30-. 35-. 43.5-wt\% Moisture).

16. Twenty-Factor Partial-Least-Squares. Second Derivative Model Predicting ail 101-SY Samples (5-. 10-. 15-. 20-. 25-wt\% Moisture). 


\section{LIST OF TABLES}

1. Tank Waste Moisture Ranges and Moisture Measurement Target Accuracies . . 4

2. Simulant Moisture Samples . . . . . . . . . . . . . . . . . . . 12

3. Root-Mean-Square Error Estimate of Partial-Least-Squares Calibration Models 


\section{LIST OF TERMS}

CPAC

DOE

FY

HLW

InGaAs

LDUA

NIR

PCR

PLS

RMSE

SRL

USQ

WHC

Center for Process Analytical Chemistry

U.S. Department of Energy

fiscal year

high-level waste

indium gallium arsenide

light-duty utility arm

near-infrared

principle component regression

partial least squares

root-mean-square error

Savannah River Laboratory

unreviewed safety question

Westinghouse Hanford Company 
WHC-EP-0839

This page intentionally left blank. 


\section{SUMMARY OF FISCAL YEAR 1994 NEAR-INFRARED SPECTROSCOPY} MOISTURE SENSING ACTIVITIES

\subsection{INTRODUCTION}

This report summarizes the work to develop and deploy near-infrared (NIR). moisture sensing technology for application to the Hanford Site's high-level nuclear waste materials. This work is jointly supported by the U.S. Department of Energy's (DOE) EM-50 Office of Technology Development Support and the EM-30 Tank Waste Safety and Tank Waste Remediation Systems Programs. A basic NIR system was developed at the Savannah River Laboratory (SRL) with support from DOE'S EM-50 Office. The application of this technology to Hanford's high-level wastes (HLW). including deployment. is supported by DOE's EM-30 Systems Programs.

The need to know the moisture content in HLW is driven by concerns for the safety of underground storage tanks that contain or are suspected of containing ferrocyanide and organic types of materials. The NIR technology has application for both ex situ (hot cell core measurements) and in situ waste tank moisture sensing.

The cold test/calibration data in this report was generated as part of the total life cycle development path being followed in the development and deployment of the NIR technology at the Hanford Site. A diagram of the steps in this process is shown in Figure 1 .

\section{Technology Development Path}

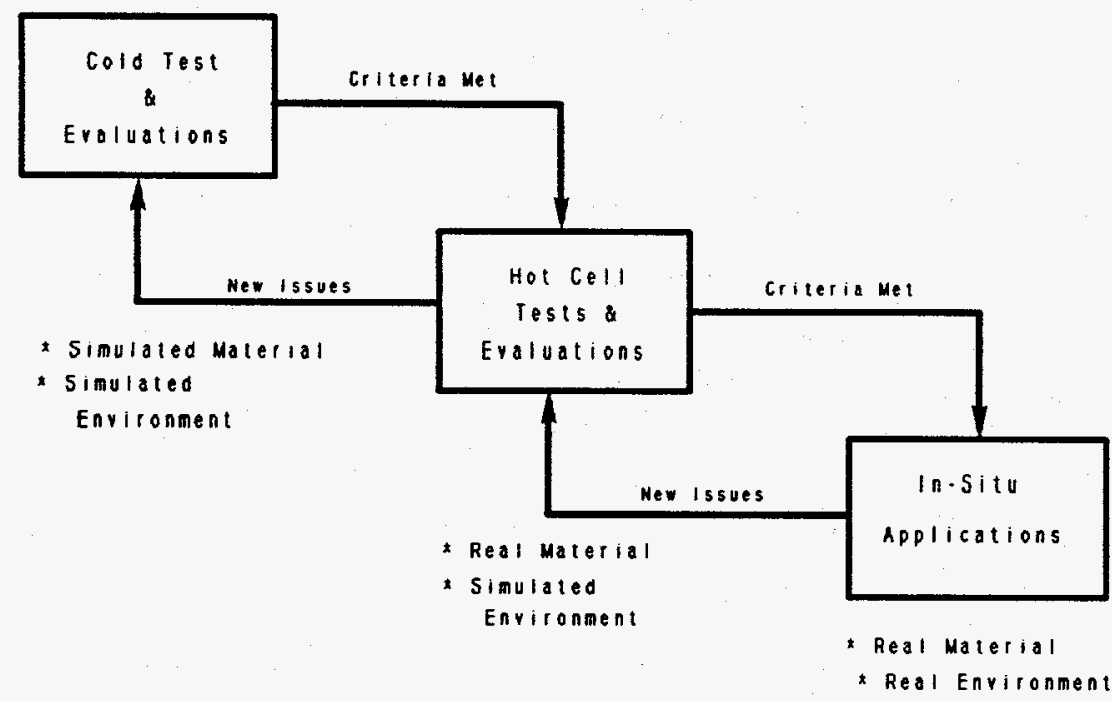

Figure 11 . Progressive Technology Development Diagram.

\subsection{SPECTROSCOPY-BASED MOISTURE SENSING THEORY}

The infrared optical properties of water are principally the result of molecular vibrational energy states. The molecular bonds of water (vibrational and rotational modes) produce strong optical absorbance bands (some are overtone bands) 
WHC-EP-0839

that range from the visible through the infrared region. as shown by the spectra in Figure 2. The absorption of water is very strong and is usually an inconvenience or interferant when attempting to use infrared for speciation and characterization. On the positive side. this strong infrared absorption produces strong overtones in the NIR optical region that are within the range of many optical and electro-optical components.

The NIR moisture sensing technology is based on the principle that optical absorption is proportional to the number of molecules illuminated by the optical beam (Veltkamp 1994b). For example. Figure 2 shows an overall global spectral change that is a function of the BY-104 tank simulant's water content. Absorption from the gaseous form of water (water vapor) is localized in specific optical bands and does not exhibit the global spectral absorption that liquid water shows. This fundamental absorption difference has been used to distinguish between optical absorption from liquid (what is in a tank sample) and optical absorption from atmospheric water vapor (what is in the tank headspace region).

The normal method of implementing quantitative analysis is to measure the optical transmission of a sample of known thickness and to correlate this with the molecular concentration. Because the tank waste materials are normally very opaque. transmission is very low and we must use the reflected or backscattered light (which contains absorption information) for moisture sensing. This is done by illuminating a sample with an optical source and collecting the reflected or backscattered light. then analyzing the spectral content with a spectrograph system. The spectrograph spatially orders the optical spectral content. producing the reflectance spectrum. Remote sensing is accomplished by coupling a fiber optic probe to the light source and spectrograph modules.

\subsection{MOISTURE SENSING TECHNOLOGY DRIVERS AND GOALS}

Moisture has been identified as one of the critical parameters that impacts the safety status of Hanford Site underground storage tanks containing organics and ferro/ferricyanide materials (Postma et al. 1994). Organics were used in some of the separations processes, and ferrocyanides were used in the management of some of the underground storage tanks in order to create storage space. The existence of these materials in the tanks raises the possibility of an unsafe condition if the moisture within the tank waste is insufficient to prevent a thermal event.

While the NIR moisture sensing technology may not replace established regulatory analysis. its development as a screening tool for both ex situ and in situ characterization offers significant reduction in time. cost. secondary waste generation. and radiation exposure. The current laboratory analysis of tank waste is both time consuming and expensive. It requires core samples to be removed from the tank and processed through a hot cell before extensive chemical analysis of subsamples. A remote NIR hot cell screening probe will augment the flow of tank materials through the hot cell by reducing the time needed to make a moisture measurement. To fully understand the conditions inside these tanks. an in situ method is needed to measure tank waste moisture content.

\subsection{SAFETY DRIVERS}

A graded safety assessment has been developed to answer the concerns about the unreviewed safety question (USQ) that exists for tanks containing ferrocyanides (Postma et a1. 1994). This graded assessment separates the waste tanks into three categories, each with varying levels of moisture and total cyanide content: 

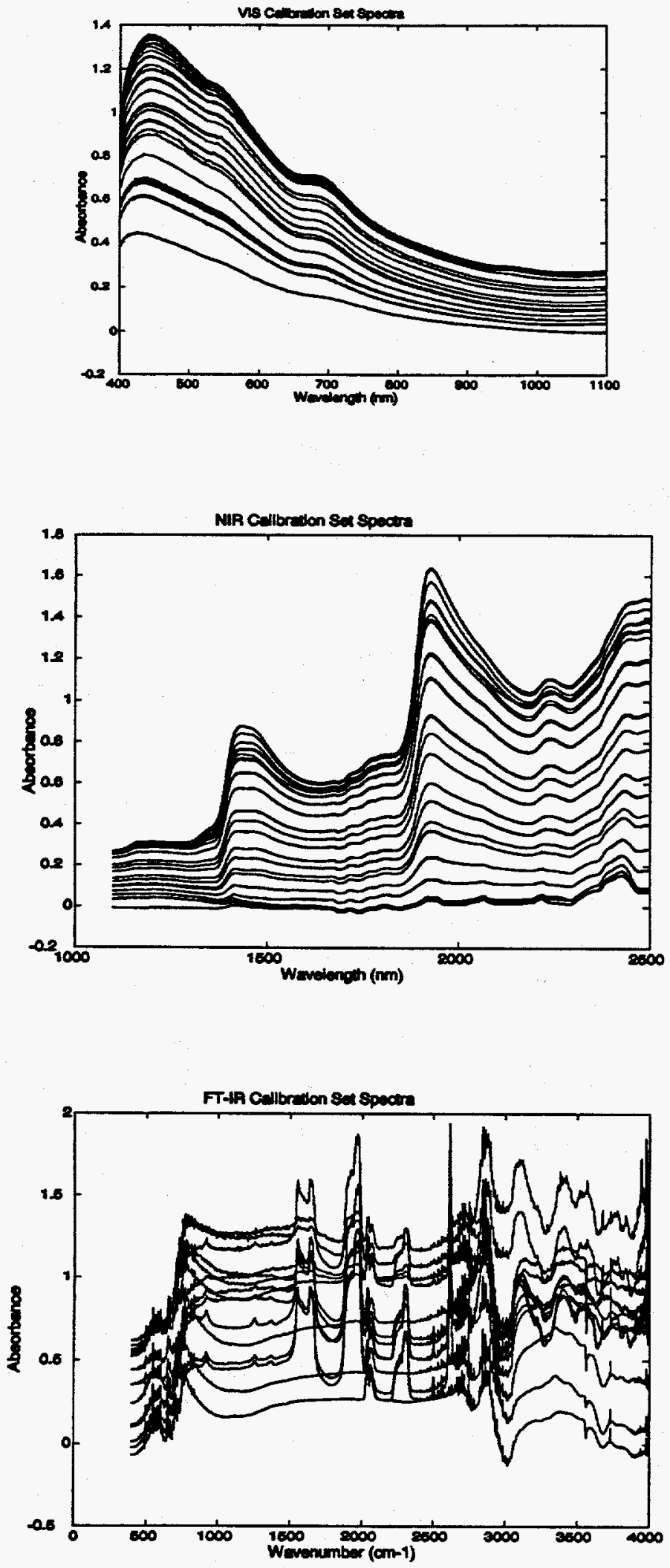

Figure 2. Visible, Near-Infrared, and Mid-Infrared Composite Spectra from Center for Process Analytical Chemistry's Task 1 Work. 
1. Intrinsically Safe - The tank waste contains more than 24-wt\% moisture (quantity of moisture expressed as a percentage of the total material weight). has unlimited total cyanide content. and it's temperature is $<90$ ${ }^{\circ} \mathrm{C}$.

2. Conditionally Safe - The tank waste contains less than 24-wt\% moisture. but no more than 8 -wt\% total cyanide. and it's temperature is $<90^{\circ} \mathrm{C}$.

3. Unsafe - The tank waste contains less than 24-wt\% moisture. more than 8-wt\% total cyanide. and it's temperature is $>90^{\circ} \mathrm{C}$.

The most recent functional requirements for in situ ferrocyanide and organic tank moisture measurements are shown in Appendix $A$. The requirements show that the total moisture target for in situ tank applications has a range of 5 to $60 \mathrm{wt} \%$. The accuracy targets in this requirement are moisture range dependent as shown below in Table 1. The table shows that with a moisture level between 5 and 30 wt\%. the accuracy of the moisture measurement needs to be within \pm 5 wt\%. Over a 31 - to 70 wt\% moisture range. a measurement with a \pm 10 wt\% accuracy is needed. For example. if the actual moisture level of the waste material is 20 wt\%. the moisture sensor could indicate a moisture level between 15 and 25 wt\% and still be acceptable for in situ waste tank use.

Table 1. Tank Waste Moisture Ranges and Moisture Measurement Target Accuracies.

\begin{tabular}{|c|c|}
\hline $\begin{array}{c}\text { Tank waste moisture range } \\
(w t \%)\end{array}$ & Moisture measurement target accuracy \\
$(w t \%)$
\end{tabular}

\subsection{DEPLOYMENT APPLICATION TARGETS}

Westinghouse Hanford Company (WHC) is working with radiation hardened and chemically hardened fiber optic probes that allow the NIR moisture sensing technology to be applied in both hot cells (ex situ) and waste tanks (in situ). In the hot cell. an NIR moisture sensing system will provide the capability to quickly obtain moisture profiles along the axis of the core sample. which is not possible with current methods. A moisture scan taken along the axis of an extruded waste core will provide homogeneity screening information that can be used to alter the extraction of core subsamples taken for detailed chemical analysis. Cost and throughput impacts are expected when the number of subsamples taken for chemical analysis can be reduced.

To support on-going hot cell core analysis, the NIR probe is being designed so that it can be interfaced with a mechanically driven core scanner module to partially automate the core scanning function.

The NIR moisture probe is also being considered for in situ tank deployment with the light-duty utility arm (LDUA) and with a cone penetrometer system. The cone penetrometer will provide moisture profiling as a function of depth while an LDUA moisture end-effector will profile the moisture content of the near surface of the waste to be characterized.

A concept for an in situ. noncontact. tank waste surface moisture camera application is also being considered. This camera would provide moisture content as a function of surface position over the waste. similar to the temperature data produced by an infrared thermal camera. 


\subsection{OPTICAL SPECTROSCOPY FEASIBILITY STUDIES}

The NIR moisture sensing system discussed below is based on a number of basic feasibility studies that have been completed with tank simulant materials. As shown in Figure 1. the use of simulant test materials is one of the steps in the progressive development path. Testing with real tank wastes is still required to validate the technology with real materials, the driver being the chemical and physical deviations found between simulants and real tank wastes.

The feasibility evaluations identified methodologies for extracting moisture data from optical spectra. These studies also helped identify and evaluate potential "show stopper" issues associated with the application of this technology to tanks and tank waste materials. This work involved offsite contracts with the University of Washington's Center for Process Analytical Chemistry (CPAC) and the University of Idaho, and cold testing work at WHC.

The results of these studies show that moisture analysis with NIR spectroscopy is a sound technology and is feasible for remote use with materials that cannot be easily handled. such as tank waste.

\subsection{BASIC NEAR-INFRARED FEASIBILITY AND SENSITIVITY COMPARISON STUDY}

The NIR moisture sensing system is based on feasibility work performed by CPAC with waste tank simulant materials. This work was completed by CPAC in a series of tasks:

Task 1 - Basic optical spectroscopy moisture sensitivity studies

Task 2 - Evaluation of potential material interferences

Task 3 - Evaluation of application-related issues.

The Task 1 study, completed in fiscal year (FY) 1993. showed that moisture could be sensed remotely using the optical scattering/absorption from the surface of saltcake (Veltkamp 1993). This work used BY-104 simulant samples that had moisture contents ranging from 0 to 24 wt\%. which is the upper concentration limit for BY-104 simulant (where water ceases to be absorbed and free-standing water appears).

Figure 2 shows CPAC-generated data for these optical regions for BY-104 simulant with water content varying from 0 to 25 wt\%. These spectra show both broad-band absorption changes, indicated by the base-line changes in the spectra. and absorption localized in spectral bands that are moisture content dependent.

This CPAC study demonstrated that it was possible to extract moisture data from optical backscattered spectra with a reasonable degree of confidence. A performance comparison was made with partial-least-squares (PLS) models from three optical regions: visible $(0.400$ to $1.1 \mathrm{\mu m})$. near infrared $(1.1$ to $2.5 \mu \mathrm{m})$. and mid-infrared (500 to $4000 \mathrm{~cm}^{-1}$ ). In each case, these model and sensitivity studies used the full spectral wavelength range. This is in contrast to WHC's work with the SRL NIR system technology. discussed below. which used only a segment of the spectrum around the $1.4 \mu \mathrm{m}$ water absorption line.

A comparison of the PLS calibration models indicated that the NIR region ( 1.5 to $2.5 \mathrm{\mu m}$ wavelength range) provided the best moisture prediction accuracy for the 
BY-104 simulant. A moisture prediction error in the range of 0.5 to 1.5 wt\% was demonstrated for moisture concentrations from 0 to 25 wt\%. Conventional optical components. including lenses and windows. optical filters. and fiber optics. are available to implement instrumentation in the NIR optical region, unlike the midinfrared region, which requires special optical methods, such as reflective optics. and is not supported with fiber optic components. The technology involved in developing the mathematical models and basic spectral data were then transferred from CPAC to WHC.

\subsection{PARTICLE AND IONIC CONCENTRATION INTERFERENCE STUDIES}

The impact of particle sizes and variations in waste ionic concentration levels (Task 2 completed by CPAC in FY-1994) were studied using the BY-104 simulant (Veltkamp 1994a). The objective of these analyses was to determine if particle size and composition sensitivities would prohibit NIR from being used with tank wastes with these as unknown features.

Three particle size ranges were selected, samples were prepared using sieving. and NIR spectra were obtained for different moisture contents within each particle range: small particles less than $420 \mathrm{\mu m}$ diameter (40 mesh). medium particles with diameters in the 420 to $840 \mu \mathrm{m}$ range. and large particles in the $840 \mu \mathrm{m}$ to $2 \mathrm{~mm}$ range.

Calibration models prepared from the NIR backscattered spectra showed that there was almost no impact on moisture sensing performance when the models and test samples had the same particle sizes: moisture prediction errors in the 0.5 - to 0.7 -wt\% range, similar to the Task 1 study. were obtained. A degraded moisture prediction accuracy occurred when the calibration and test models had different particle size ranges. However. an overall model with all particle sizes still provides accuracies within \pm 1 wt\% for samples with selected particle size ranges. Although particle size variations did impact calibration performance, the error was small and compensation was possible if models were made with samples having different particle size ranges.

Moisture sensitivity tests were completed with BY-104 samples in which the ionic concentrations of the major chemicals were varied. The nature of the composition effect was dependent both on the simulant components and the moisture level of the sample. In these tests. a calibration model was set up using BY-104 simulant with the established recipe concentrations unchanged. Then the concentrations of key species were increased. Sample moisture was progressively changed and NIR spectra were obtained and evaluated against the basic BY-104 calibration model. For $\mathrm{NaOH}, \mathrm{NaAlO}_{2} \cdot \mathrm{Na}_{2} \mathrm{SiO}_{3}$, and $\mathrm{Na}_{3} \mathrm{PO}_{4}$. there was a bias toward a lower-than-actual moisture reading. Changes in $\mathrm{Fe}\left(\mathrm{NO}_{3}\right)_{3}{ }^{\circ} \mathrm{Ca}\left(\mathrm{NO}_{3}\right)_{2}$. and $\mathrm{Mg}\left(\mathrm{NO}_{3}\right)_{2}$ content produced a higher moisture reading bias. The root-mean square error (RisE) moisture prediction errors from the chemical changes ranged from 0.7 to 2.3 wt\% per 1-wt\% change in the chemical species (Veltkamp 1994a). A calibration model was then developed with NIR spectra ( 1.5 to $2.5 \mu \mathrm{m}$ wavelength range) from samples with all of the concentration changes. With this combined model, a moisture prediction accuracy of better than \pm 1.41 wt\% was obtained. This shows that accuracy can still be maintained if models are constructed with samples having the range of chemical compositions in them.

\subsection{ATMOSPHERIC MOISTURE INTERFERENCE STUDIES}

A third task completed by CPAC (Veltkamp 1994b) and WHC involved modeling studies that demonstrated a strong interference from atmospheric moisture content 
with optical systems that have long open optical path lengths, such as an in situ. non-contact camera type of system. To complete these studies. NIR spectra (1.5 2.5 micron) from BY-104 moisture samples were modified with atmospheric absorption data obtained from computer atmospheric moisture model. The computer model allowed both atmospheric path length and humidity level over the path length to be varied. The resulting spectra simulated the performance of an optical system having an open atmospheric path that a non-contact camera type system would have if it was operating in the head-space region of an underground storage tank.

Two methods of mitigation were identified and evaluated with computer modeling: (1) path length/relative humidity corrections applied to corrupted NIR atmospheric sample spectra and (2) PLS modeling with spectra containing water vapor as an interferant. Work done by CPAC showed that the effects of the headspace could be corrected by a second order equation, knowing the volume of water being intercepted in the optical path (combined impacts of optical path length and relative humidity in the headspace region). A more robust solution used the NIR spectra with atmospheric absorption expressed as an interferant to develop a PLS calibration mode1. These PLS models with water vapor as an interferant were able to predict moisture from the NIR spectra of BY-104 simulant samples with predictions errors in the 0.729 - to $0.743-$ wt\% range.

\subsection{MATERIAL IMPACTS ON SENSING VOLUME}

An initial assumption with the NIR spectroscopy concept was that the depth of penetration was limited to the first few micrometers of surface material. It was thought that tank materials were strong optical scatters and very opaque so that the backscattered light came from only the surface of the sample. This assumption came under serious question after testing work with pure sodium nitrate moisture standards indicated that the depth of penetration was a function of the moisture content as well as other material properties. Sodium nitrate was used because it represented a worst-case scenario for one of the saltcake simulants (BY-104 simulant material). These tests showed that for dry materials (approximately 0 -wt\% moisture content) the backscattering was nearly a surface property: good NIR spectra could be obtained with a relatively thin layer of material. As the moisture was increased. the amount of backscattering decreased and more of the light penetrated the bulk material. For a fully saturated sodium nitrate sample, 20- to 25-wt\% moisture content. a sample thickness of over $1.27 \mathrm{~cm}$ was required.

When testing the tank simulant materials, it was found that increased water appeared to produce a darkening of the samples. This was found for all four tank simulant materials. It appears that the water decreases optical scattering and facilitates the coupling of light into absorbing crystals by providing a better refractive match than an air interface.

This relationship with water content prompted the placement of a study contract with the University of Idaho to examine the material impacts on the depth of penetration in backscatter measurements. The results of this study are due at the end of December 1995.

\subsection{DESCRIPTION OF THE SAVANNAH RIVER LABORATORY'S NEAR-INFRARED HOT CELL SYSTEM}

The moisture sensing NIR system, including the fiber optic probes, that was used in the test and demonstration work described below was developed by SRL. Unlike the generic spectrograph systems used by CPAC in their studies, this system 
was specifically designed for remote NIR spectroscopy measurement applications. One of the key differences is that the spectrograph grating and optical detector were designed for operation over a 1.0 to $1.7 \mathrm{\mu m}$ wavelength range. which includes the 1.4 to $1.5 \mathrm{\mu m}$ water absorption band (an overtone band). The CPAC feasibility studies above used a much broader NIR optical region $(1.5$ to $2.5 \mathrm{\mu m})$. This reduction in the spectral data field is thought to have a slightiy negative impact on the moisture prediction performance but was not verified. The SRL system is a compact NIR system with a degree of ruggedness that allows it to be transported with little effect on the system's performance.

A diagram of the SRL NIR moisture sensing system in a hot cell application is shown in Figure 3 . The system components include (1) a near-infrared source (NIR lamp). (2) fiber multiplexer. (3) a bifurcated fiber optic probe. (4) spectrograph. (5) indium gallium arsenide (InGaAs) NIR detector array, and (6) computer data acquisition and control system.

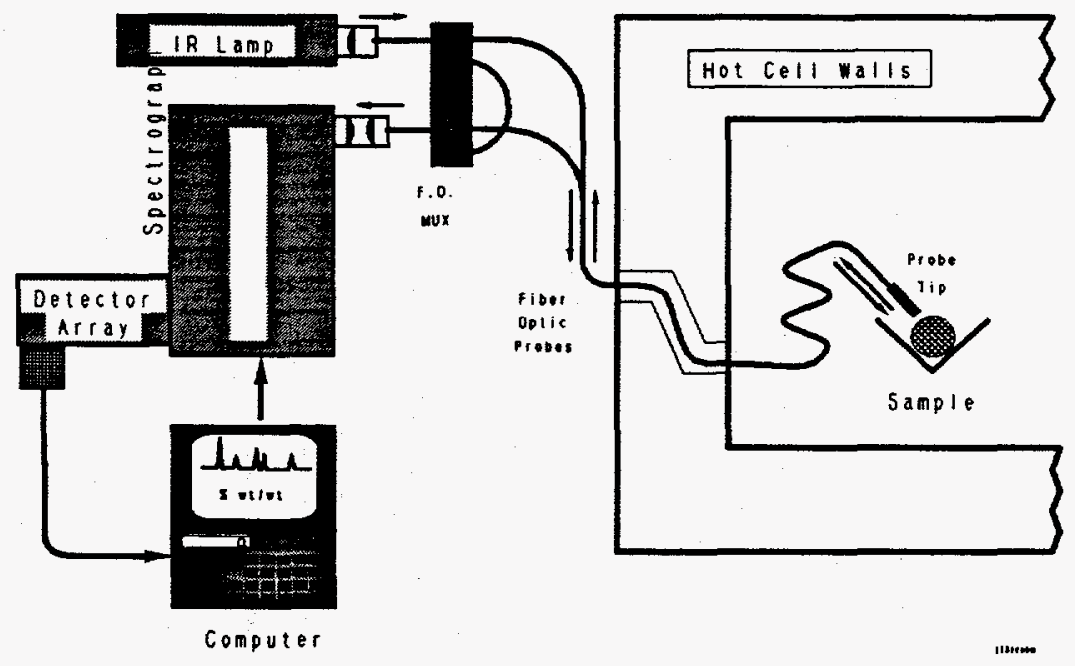

Figure 3. Hot Cell Near-Infrared System.

1. The infrared light source is a tungsten-halogen lamp. The lamp itself was built into the multiplexer and directly couples light into the fiber optic probe.

2. The multiplexer switches the lamp source and spectrograph between the fiber optic probe and a reference. For these cold tests, the reference was a fiber optic loop that ran directly from the lamp source to the detector. The multiplexer is controlled by a stepper motor controller from the computer system.

3. The sample fiber optic probe is a 6-around-1 fiber optic design (the probe tip is arranged with 6 fibers in a circle around a central optical fiber) with a cone-shaped tip. The cone tip "bends" the light from the 6 "around" fibers toward the central axis of the probe. This provides a cross-over of light with the optical field of the central fiber. 
4. In the sample probe the 6 "around" fibers are used for illumination while the single central fiber collects the scattered/reflected light for input to the spectrograph. This light is transmitted through the single-fiber leg back to the multiplexer port that is input to the spectrograph.

5. The spectrograph takes the light and spatially orders its wavelength content. The InGaAs focal plane detector provides an electronic readout of the wavelength dispersion (spectrum). The spectrograph is connected to the multiplexer by the single fiber of the fiber optic probe.

6. The InGaAs detector array is connected to the computer's central processing unit via a serial. general purpose, interface bus cable. This is a thermoelectric-cooled detector array with an air exchange heat sink (provision is made for water cooling. but the array was cooled sufficientiy with just an air exchange so this option is not used). An air pump draws air through a desiccant to provide a small source of clean. dry air over the surface of the array.

7. The computer system consists of an IBM ${ }^{1} 386$ personal computer with a general purpose interface bus input/output card and software that controls and communicates with the detector array controller and the multiplexer controller. Software in this computer system also processes the spectrum and applies it to the stored calibration models that provide the moisture content estimates.

8. The multiplexer provides fiber optic switching so that the spectrograph system can obtain white light spectra from an optical fiber loop and a dark current spectrum (no illumination reaching the detector array). The dark current spectrum is subtracted from a measurement spectrum to remove the detector array's dark current signal. The detector array's pixels do not have a uniform optical response and the "white light" spectrum provides an optical reference from which these spectral variations in the array can be corrected.

\subsection{ISSUES WITH THE SAVANNAH RIVER LABORATORY'S NEAR-INFRARED SYSTEM}

Upon receipt of the first SRL-developed NIR moisture monitoring system. several technical challenges and issues with both the hardware and software were encountered. The diagnosis of software and hardware problems was complex because it was very difficult to separate software failures from hardware failures. The acquisition of separate software programs to independently exercise the modules greatly assisted in problem diagnosis.

\subsubsection{System Hardware and Software Documentation}

The SRL NIR spectroscopy system was received without complete system-specific documentation. A generic description of the software package was made available. but this did not include operator guidance for basic startup and operating procedures. A draft working manual was developed by WHC that covered basics on system setup and operation as applied to sensing moisture. The draft now needs updating to include changes and operating issues that were identified and addressed in testing and demonstration activities.

1 IBM is a trademark of the International Business Machines Corporation. 
One of the problems with the SRL NIR system software was that it was designed for generic spectroscopy use and was not limited to moisture sensing. There were no specific operating instructions or safeguards for critical instrument settings in the software. As a result. settings could be inadvertently changed. causing the system to abort or lock up. In such cases. trial and error was used to ferret out which settings were changed and to fix the problem. The solution taken by WHC was to document all settings. defining their purpose and identifying default values. In addition. SRL provided some software modifications to ensure that a user has no need for software options that are associated with critical system settings (system related setups/configurations and software processing default settings).

\subsubsection{Hardware Issues}

Several hardware malfunctions and problems were encountered with the SRL NIR system that caused operational difficulties and contributed to time delays in the achievement of testing and calibration objectives.

As originally designed. the light source and detector air pump (for pumping dry air over the thermoelectrically cooled detector array) drew their power from the disk drive power source in the central processing unit. This power load caused problems with data transfer from memory to diskettes. The problem was fixed by incorporating a separate power supply into the system for these components.

After a couple months of system operation. the fiber optic multiplexer failed. The diagnosis was very difficult because of the interaction between the spectroscopy software and the hardware. In replacing components. it was discovered that there was a catastrophic interaction between the driver module and the driver motor that caused new components to fail. This was fixed by simultaneously replacing both driver and motor. but only after several of each were damaged.

While trying to get a second NIR system operational, it was noted that there were problems in the acquisition of the spectral signal from the InGaAs detector array. A separate detector array operating with software from a commercial supplier was used to diagnose the detector failure. The failure was determined to be in the pixel blanking board. which is used in processing the signal from the detector chip. The detector systems were returned to the manufacturer for repairs.

Problems were also encountered with the fiber optic probe: cracked optical fibers and window epoxy failures. Early in testing. the fibers in one of the probes were cracked and had to replaced. Test procedures were modified to ensure that "over-bending." which was conjectured as the cause of the failure. was eliminated. The fiber optic probe window was attached with epoxy to a removabie ferrule that screwed on to the probe tip. The window prevented the probe tip's fiber optic surface from contacting waste materials and set a lift-off distance so that the illumination and collection fibers were optically coupled at the sample surface. During use in the caustic simulant materials. the epoxy failed, the window detached. and it was sometimes lost in the test materials. A different epoxy was used to reattach the window. In addition, a design change. which used a "keeper" ring to hold the window against the probe. was identified and initially tested. It is conjectured that the initial brand of epoxy was chemically affected and degraded by the caustic simulant materials.

\subsubsection{Combined Hardware and Software Issues}

The calibration model supplied with the SRL NIR system was originally developed with a very limited data set (BY-104 material with a 0 - to 25 -wt\% moisture content). 
In trying to create a new calibration model with a larger range of materials and moisture levels. errors in the model-building software were found.

A limitation of the SRL software was found during development of the calibration models used to extract moisture content data from the NIR spectra. In order to obtain data that meets the requirements of the application. it is necessary to build the model from a rather large sample matrix. The SRL software allows only a limited number of samples to be used in building calibration models. As will be explained further in later sections. this is a critical issue for this application.

To complete this campaign it was necessary to do the statistical processing with other software packages. Work was initiated with a Matlab ${ }^{2}$-based software package that performs PLS processing with stored or archived spectral data.

A commercially available replacement unit for this moisture sensing system was identified and a unit was purchased. The performance of this system will be evaluated to determine which system should be use for hot cell deployment and testing. The SRL NIR system is not currently functioning in a manner that would allow it to be run by an unexperienced operator.

\subsection{TANK SIMULANT MOISTURE TEST SAMPLES AND MEASUREMENT PROCEDURES}

The system calibration model is an essential part of the NIR moisture sensing process because it provides the linkage between a spectral measurement and a moisture readout. The "goodness" of the calibration model is dependent on the selection and preparation of "standard" samples.

For the cold calibration work. a number of tank simulants were chosen because of their ability to represent a partial range of optical. physical, and chemical properties suspected of being present in real tank wastes (testing with real tank materials is needed to confirm the range of tank materials these simulants represent).

1. BY-104 - This material simulates the waste tank salt material from waste tank BY-104. The BY-104 simulant represents the saltcake material. anticipated to be on or near the surface crust of stabilized saltcake tanks (constituent list in Appendix B).

2. T Plant, Top Fraction - This material simulates the top portion of a tank containing a slurry or sludge with ferrocyanide materials. The T Plant simulant represents the sludge-like materials found under these crust layers in stable tanks. The T Plant simulant also has cyanide compounds representative of the level expected in the tank wastes (constituent list in Appendix $B$ ).

3. T Plant, Bottom Fraction - This material simulates the bottom portion of a tank containing a slurry or sludge with ferrocyanide materials (constituent list in Appendix B).

4. 101-SY - This material simulates a complexed waste (Hanlon 1994) containing significant amounts of organics. It models the conductive. slurry portion of tank 101-SY (constituent list in Appendix B).

2 Matlab is a trademark of The Mathworks. Inc. 
All these simulants appear optically dark. which suggests high optical absorption. However. each simulant exhibits unique optical features. Figure 4 shows that there are optical differences between simulants, which is expected. but that there are also significant optical differences related to water content for each simulant. An example of differences between simulants is the green tint of the 101-SY simulant and the rich brown color of the BY-104 simulant. A11 of the simulants became darker with increased moisture content. This optical variation with water indicates that the current hot cell technique of using visual inspection to determine sampling may be falsely biased. The color acuity in a hot cell is also strongly biased by the optical properties of the lead glass window. From these simulant tests. it is unlikely that either chemical differences or moisture changes can be adequately determined through visual inspection.

\subsection{SAMPLE PREPARATION}

The simulants were first dried in an oven at $110^{\circ} \mathrm{C}$ for 24 hours or more to drive off most of the moisture. This low temperature was used to ensure that all of the simulants would remain chemically unchanged. The dried materials were then ground with a coffee grinder to produce a uniformly fine powder (recommended by CPAC as a substitute for a more expensive laboratory ba11 mi11 or grinder). This grinding process was used after it was found that particle size and uniformity were found to affect the ability to produce a homogeneous distribution of water in the simulant: large particles tended to "latch" on to water droplets. After grinding. the samples were dried again.

Moisture standards were then made by progressively adding measured weights of water to the sample (verified by subsample's weight increase), thoroughly mixing. and extracting a subsample. The water was added in very smali amounts and stirred vigorously to break up all clumps that formed in the material. (CPAC studied three different methods of sample preparation and found nonmeasurable variations in the samples when tested with NIR methods). A 2- to 3-g subsample was then taken from the bulk sample. which now contained a known weight percent of water. This subsample was placed in a sealed, labeled vial.

The weighing. water addition. mixing, and subsampling cycle was then repeated until the bulk sample material became saturated with water. indicated by the simulant moisture ranges shown in Table 2. Each of the simulant samples exhibited unique moisture holding characteristics. Although the critical moisture level from a tank safety aspect is set at a 24-wt\% level, the in situ moisture measurement need is from 5 to $60 \mathrm{wt} \%$. In Table 2. the "Total moisture range" is the experimentally determined maximum amount of water that a sample can hold without free water visually existing. The "Actual sample moisture levels" show the results of the moisture preparation cycle for each simulant material.

Table 2. Simulant Moisture Samples.

\begin{tabular}{|l|c|l|}
\hline \multicolumn{1}{|c|}{ Simulant material } & $\begin{array}{c}\text { Total moisture range } \\
\text { (wt\%) }\end{array}$ & \multicolumn{1}{|c|}{$\begin{array}{c}\text { Actual sample moisture levels } \\
\text { (wt\% units) }\end{array}$} \\
\hline 101 -SY simulant & 5 to 25 & $5,10,15,20,25$ \\
\hline BY-104 simulant & 0 to 25 & $0,5,10,15,20,25$ \\
\hline T Plant bottom simulant & 5 to 40 & $5,11,18,25,30.35,44$ \\
\hline T plant top simulant & 10 to 60 & $\begin{array}{l}5,9,13,30,32,37,42.47 . \\
50,55.60\end{array}$ \\
\hline
\end{tabular}




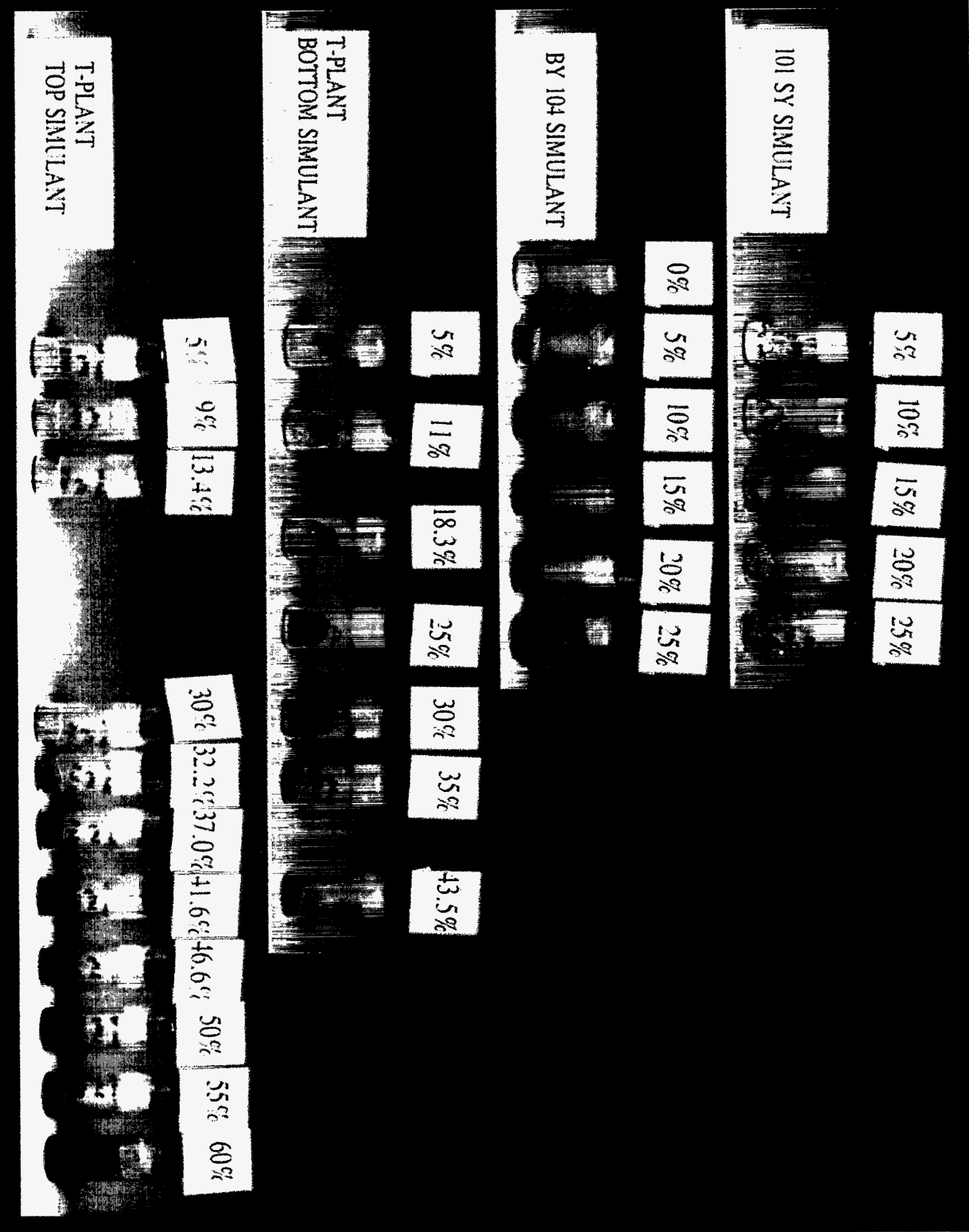

Figure 4 Photo of samples used during testing of SRL NIR system. 


\subsection{SAVANNAH RIVER LABORATORY'S NEAR-INFRARED SYSTEM SPECTRUM MEASUREMENT PROCEDURE}

A spectrum measurement procedure was established experimentaliy and then used to obtain representative and repeatable spectral data from test samples. A11 measurements from a simulant type were obtained before addressing another tank simulant. The concerns addressed by the procedure included the following:

- Cross-contamination between samples. especially dry samples or samples containing very little water

- Optical changes (opacity and scattering) that varied between simulants and within simulants with different water content

- Light escaping from the sides of the vial because of too little sample volume between the probe and the vial side

- Extraneous room light reaching the probe through either the sides or bottom of the sample.

It was found that with some samples. it was necessary to have several cubic centimeters of sample so that light was not being lost by the sample and so that room light was not penetrating an optically thin sample. The thickness depended on the opacity of the sample.

Some of the medium moisture content samples (101-SY in particular) tended to clump into a solid and become very hard after the moist sample sat for a short time. This made it difficult to get a good solid contact interface with the probe window and often good optical coupling was not possible. Some of the error in the middle moisture ranges seemed to be affected by this sample behavior.

\subsection{TEST PROCEDURE}

1. Insert fiber probe tip into the sample such that the probe window is in uniform contact with the sample.

NOTE: The approximate path length of the scattered light in this situation is about $1 \mathrm{~mm}$.

2. Take NIR spectra at several different probe positions within the sample and observe the reading on the maximum signal or count level of the spectra. Adjust the detector integration or exposure time to achieve a count level near the upper 75 percent of the detector array's maximum signal range.

3. Note any anomalies in the spectra (spectral shapes that are significantly different from the spectra shown in Figure 2). Anomalies are large spectral changes from the average shape of all of the samples' spectra. Areas of saturation are also of concern. If anomalies occur, reposition the probe and resample the spectra.

4. Record spectra from different probe positions within the sample with the set exposure settings.

5. Take a reference spectrum and a dark current spectrum. This is an automatic function performed by the fiber optic multiplexer. These spectra are used in the calibration and normalization of the spectra from the moisture samples. 
6. After probing a sample, clean the probe with distilled water and dry thoroughly (paper towel).

7. Verify moisture weight percent by weight loss after drying samples.

\subsection{SAVANNAH RIVER LABORATORY'S NEAR-INFRARED MOISTURE SAMPLE SPECTRAL DATA SET}

The spectral data set for all four tank simulants and all of the moisture levels is shown in Figure 5 . This includes the overtone water absorption band that is centered on $1400 \mathrm{~nm}$. The SRL NIR system acquired spectral data over the range (1100 to $1700 \mathrm{~nm}$ ). but the usable spectral range was truncated to eliminate noise and to concentrate modeling on the most active region of the water absorption band (system-induced noise spikes appear at about 1200 and $1400 \mathrm{~nm}$ ). The 256-element detector array gave a spectral point every $2.54 \mathrm{~nm}$ over this wavelength region.

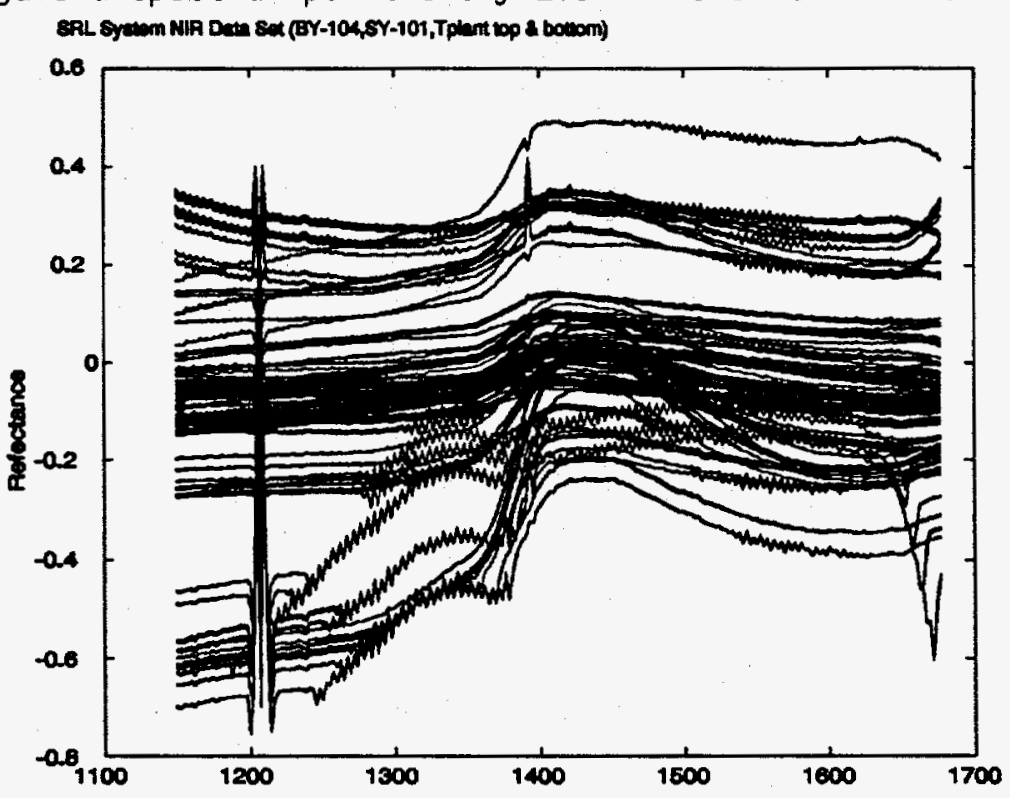

Figure 5. Spectral Data Set Measured From all Waste Tank Simulant Moisture Samples.

\subsection{CALIBRATION DEVELOPMENT AND EVALUATION}

In developing calibration models, the objective was to derive a model that produced a minimum prediction error with the tank waste simulant materials. The performance of this model with simulant materials would then provide a demonstration of the potential system performance with actual tank materials. The data acquisition and model development and testing included the following:

- Acquisition of NIR spectra from simulant samples with known moisture content (approximately 15 to 25 spectra were taken for each sample)

- Premodel spectrum processing. such as smoothing or filtering and baseline removal with first and second derivatives 
- Construction of calibration models with these preprocessed spectra that were

- Representative of each individual simulant

- Representative of all simulants

- Numbered differently from coefficients (or degrees of freedom) in the models

- Construction of calibration models omitting selected sample and simulant data (omitted elements represented "unknown" moisture samples for system performance testing)

- Completion of tests showing moisture prediction performance for each model or identifying parameters that influenced moisture prediction performance error

- Demonstrating the moisture prediction performance with "unknown" moisture samples.

\subsection{CALIBRATION MODELS: CONSTRUCTION AND TESTING}

Models were built using both PLS and principal-component-regression (PCR) analysis techniques. Most of the calibration work was done with PLS. which. as indicated by the simulant results below. gave a superior prediction result with smaller prediction error over the moisture ranges. PLS regression works by projecting many $X$ (wavelength) variables to a few $T$ variables. These $T$ variables are then used in the prediction of $Y$ (moisture concentration). PLS differs from PCR in that PLS uses the $Y$ variables actively to reduce the effect of large but irrelevant $X$ variations during modeling. In this way PLS can develop somewhat simpler calibration models than PCR methods can. During our testing PLS models outperformed PCR because of this reduction of irrelevant information.

\subsubsection{Partial-Least-Squares Model Equation}

If we allow $A$ to be the number of factors used in the building of a model, we solve the following equations for $a=1,2 \ldots \ldots$ :

Find the unit vector $\hat{w}_{a}$ that maximizes $\hat{w}_{a}^{\prime} x_{a-1}^{\prime} y_{a-1}$.

Then solve:

$$
x_{a}=x_{a-1}-\hat{t}_{a} \hat{p}_{a}^{\prime} \text { and } y_{a}=y_{a-1}-\hat{t}_{a} \hat{q}_{a}^{\prime}
$$

where:

$$
\hat{t}_{a}=x_{a-1} \hat{w}_{a} \cdot \hat{p}_{a}=x_{a-1}^{\prime} \hat{t}_{a} /\left(\hat{t}_{a}^{\prime} \hat{t}_{a}\right) \text {. and } q_{a}=y_{a-1}^{\prime} \hat{t}_{a} /\left(\hat{t}_{a} \hat{t}_{a}^{\prime}\right)
$$

(Martens and NæS 1989).

\subsubsection{Comparison of Principal-Component-Regression and Partial-Least-Squares Models}

Comparison of PCR and PLS model performance data showed that the PLS models outperformed PCR-based models. Figure 6 . which is representative of this 
performance, shows the moisture prediction error as a function of moisture content for samples from 101-SY simulant in which both models used second derivative preprocessing and 10-factor models. The prediction error (vertical axis) is the difference between the samples' actual water content and the water content predicted by the mode1. Although the errors are not consistent over the 0 - to 25-wt\% range. the PLS error band is within \pm 1 wt\% compared to the PCR band. which is within \pm 1.5 wt\% with the exception of the one PCR response at 23 wt\%. Other performance comparison tests run with different tank simulants and different numbers of model factors showed a similar superior PLS performance. This provided the basis for using the PLS-based calibration models to complete the cold demonstration work.

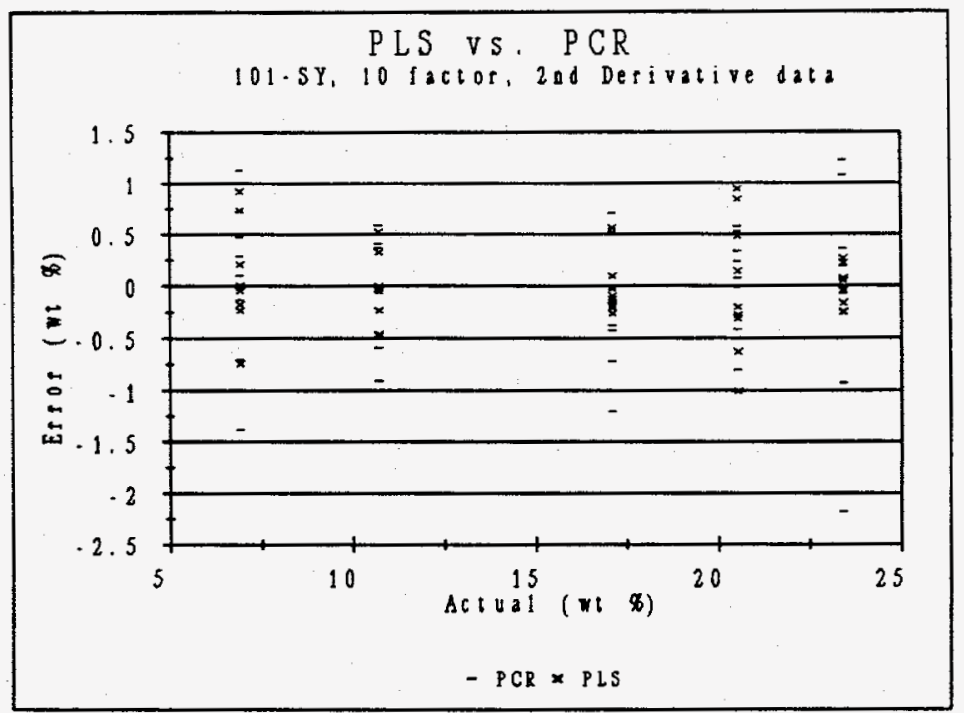

Figure 6 Comparison of PLS and PCR 10 factor calibration models from 101-SY simulant moisture samples with 2nd derivative pre-processing.

\subsection{WASTE TANK SIMULANT CALIBRATION MODEL ANALYSIS}

The purpose of investigating model parameters was to identify model construction issues that impacted moisture prediction accuracy.

\subsubsection{Premodel Spectral Data Processing}

7.2.1.1 Spectral Data Smoothing. All data was initially smoothed to remove spikes. A couple of standard methods were evaluated and it was found that similar results were obtained with all methods. Each method used a box car smoothing function that takes several points on each side of the point of concern and develops a new value for the point based on these adjacent points. The type of function used to process the adjacent point's value determines the type of smoothing.

In processing the data for their feasibility studies. CPAC used a straight averaging function in which the point of concern was set as the average of the points around it. Two functions for spectral smoothing were evaluated by WHC: a second order Savitzky-Golay function and a Gaussian function (Merier and Zund 1993). The Savitzky-Golay function set the points in the smoothing window to a second order equation with a parabolic weighting function. The Gaussian function fits the data in a similar fashion but uses a Gaussian curve to weight the influence of the neighboring points in the smoothing window. Both functions were used below with interchangeable results. 
7.2.1.2 Mean-Centered, First, and Second Derivative Preprocessing. Models were buit using smoothed data that was preprocessed by three different techniques. The first form involved a standard mean centering of the raw spectral data as obtained directly from the detector array (Martens and Næs 1989). The other two preprocessing methods consisted of taking the first and second derivatives of the spectral data. A comparison of these preprocessing options is discussed below since there are other factors that impact the choice between these options.

\subsection{SINGLE SIMULANT MODELS}

Using a single-simulant material, it was observed that the best model performance was given with the second derivative. However, it was found that in models developed with a large number of factors (more than five), the mean-centered and first derivative preprocessing methods also appeared to give a very satisfactory error result. Figure 7 compares the moisture prediction response for spectral data taken from BY-104 samples and preprocessed using first and second derivative functions for a PLS 10-factor model. The graph shows the prediction error which is the difference between the actual moisture content and the PLS model calculated moisture value. as a function of sample's actual moisture content. The error with second derivative preprocessing. over a moisture range of 0 to $20 \mathrm{wt} \%$. is within a \pm 1.5 wt\% error boundary. The first derivative error is slightly larger but within a \pm 2.5 wt\% band. Both of these meet the requirements listed in Postma et a1. (1994). but they show that there is a slight advantage to the second derivative preprocessing.

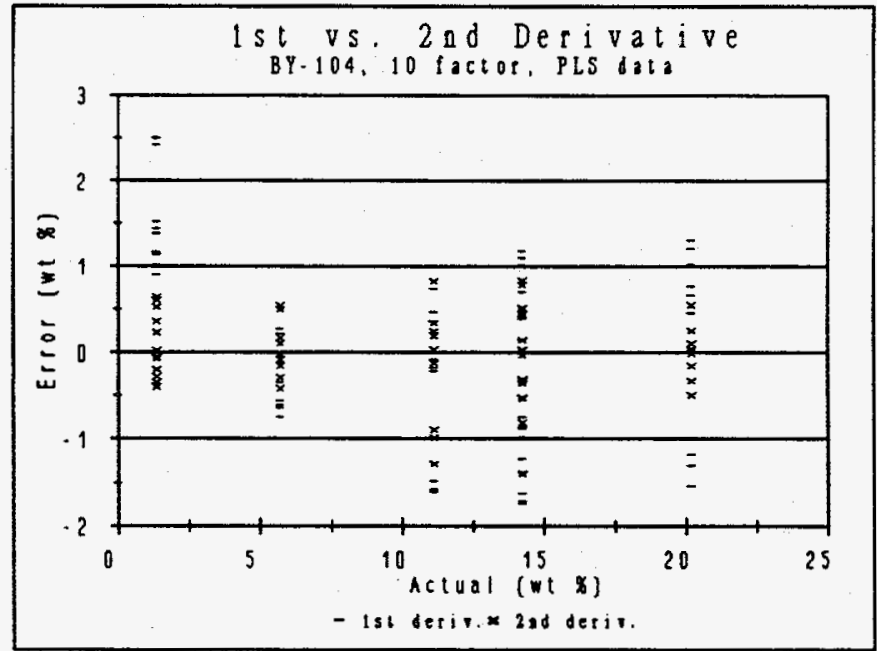

Figure 7. Comparison of First and Second Derivative Preprocessing with a 10-Factor Partial-Least-Squares Model

Built from BY-104 Moisture Samples.

\subsection{MODEL PERFORMANCE FOR COMBINED SIMULANT DATA}

The PLS calibration models using spectral data from all tank simulants were examined with several different parametric variations, including preprocessing and the number of model coefficients. All of the spectral data were first smoothed before preprocessing was completed.

The performance of the 20-coefficient PLS models as a function of actual moisture content is shown below in Figures 8, 9. and 10 for the three different 
preprocessing methods. The solid line on each graph is a \pm 5 wt\% error band. The features of these graphs to be noted are the closeness of the clusters of data points and the offset from the actual moisture content.

Since the comparison of a number of graphs. as shown in Figures 8. 9. and 10 . can be tedious. the performance was summarized in two ways. A comparison of the PLS models' RMSE estimate for moisture prediction is shown in Table 3.

In general. the best overall moisture predicting performance was produced by a 20-coefficient model using smoothed spectral data and first or second derivative preprocessing. By observation of data clustering in Figure 10, the second derivative model is better in the lower moisture ranges that are of higher concern. as was indicated above in the discussion on tank material moisture sensing target needs. Figure 10 shows that the errors of prediction from the second derivative all fall within an envelope of $\pm 5 \mathrm{wt} \%$. This "total error" band is comparable to a \pm 3 sigma confidence level.

Table 3. Root-Mean-Square Error Estimate of Partial-Least-Squares Calibration Models as a Function of Preprocessing and Number of Model Factors.

\begin{tabular}{|c|c|c|c|}
\hline \multirow{2}{*}{$\begin{array}{c}\text { Number of PLS model } \\
\text { factors }\end{array}$} & \multicolumn{3}{|c|}{ Preprocessing: (RMSE in wt\% units) } \\
\cline { 2 - 4 } & Mean-centered & First derivative & Second derivative \\
\hline 1 factor & 14.12 & 12.78 & 13.03 \\
\hline 3 factor & 7.84 & 7.56 & 11.52 \\
\hline 5 factor & 5.98 & 6.15 & 9.75 \\
\hline 10 factor & 4.36 & 3.84 & 5.81 \\
\hline 15 factor & 2.81 & 2.45 & 2.62 \\
\hline 20 factor & 1.91 & 1.49 & 1.56 \\
\hline
\end{tabular}

RMSE = root-mean-square error

$\mathrm{PLS}=$ partial least square.

The following conclusions can be drawn from the comparison data shown in Table 3 and in Figures 8. 9. 10. 11a and 11b.

- Calibration models with larger numbers of factors tended to produce smaller prediction errors than models with smaller numbers of factors. As indicated in Table 3, this trend is independent of the spectral preprocessing method used. However. the amount of improvement resulting from each additional model factor diminishes as the number of factors increases.

- Models built with data from a single tank simulant outperformed or had smaller error predictions than models made with combined simulant data.

- Over a total 0- to 60-wt\% moisture range, the first derivative preprocessing method appears to be slightly superior to the second derivative preprocessing method. For models with combined tank simulant data. the second derivative preprocessing method was superior for moisture levels below 20 wt\%. Figure 10 shows a much tighter clustering of the data points for the second derivative than for either the meancentered or first derivative preprocessing methods for moisture levels below 20 wt\%. This was also a conclusion form an earlier CPAC study with BY-104 simulant and moisture in the 0 - to 20 -wt\% range. 


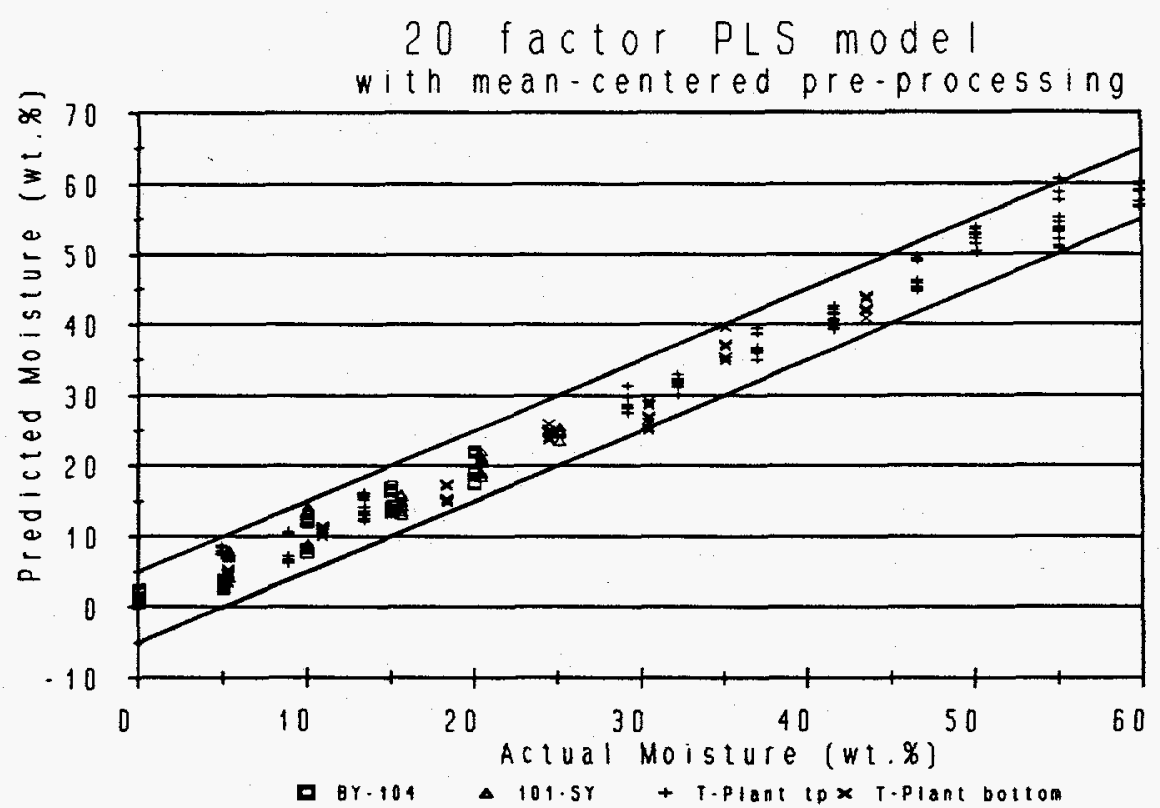

Figure 8. Twenty-Factor Partial-Least-Squares Model with Mean-Centered Preprocessing.

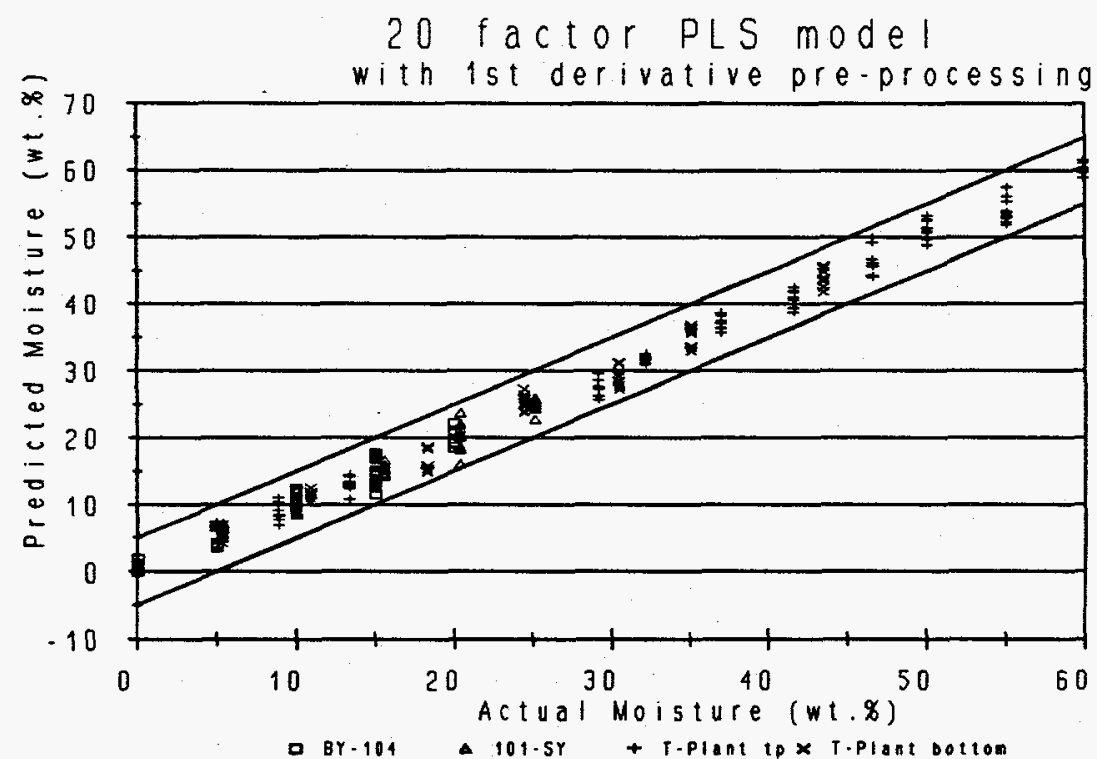

Figure 9. Twenty-Factor Partial-Least-Squares Mode1 with First Derivative Preprocessing.

- For models built from single simulant data. the second derivative preprocessing method was superior. independent of the number of model coefficients. For example. Figure 7 shows an obvious accuracy advantage of second derivative preprocessing over first derivative preprocessing for a 10-coefficient PLS model. The error with second derivative preprocessing. over a moisture range of 0 to 20 wt\%. is within a \pm 1.5 wt\% error boundary while the first derivative error is slightly larger but within a 2.5-wt\% band. 


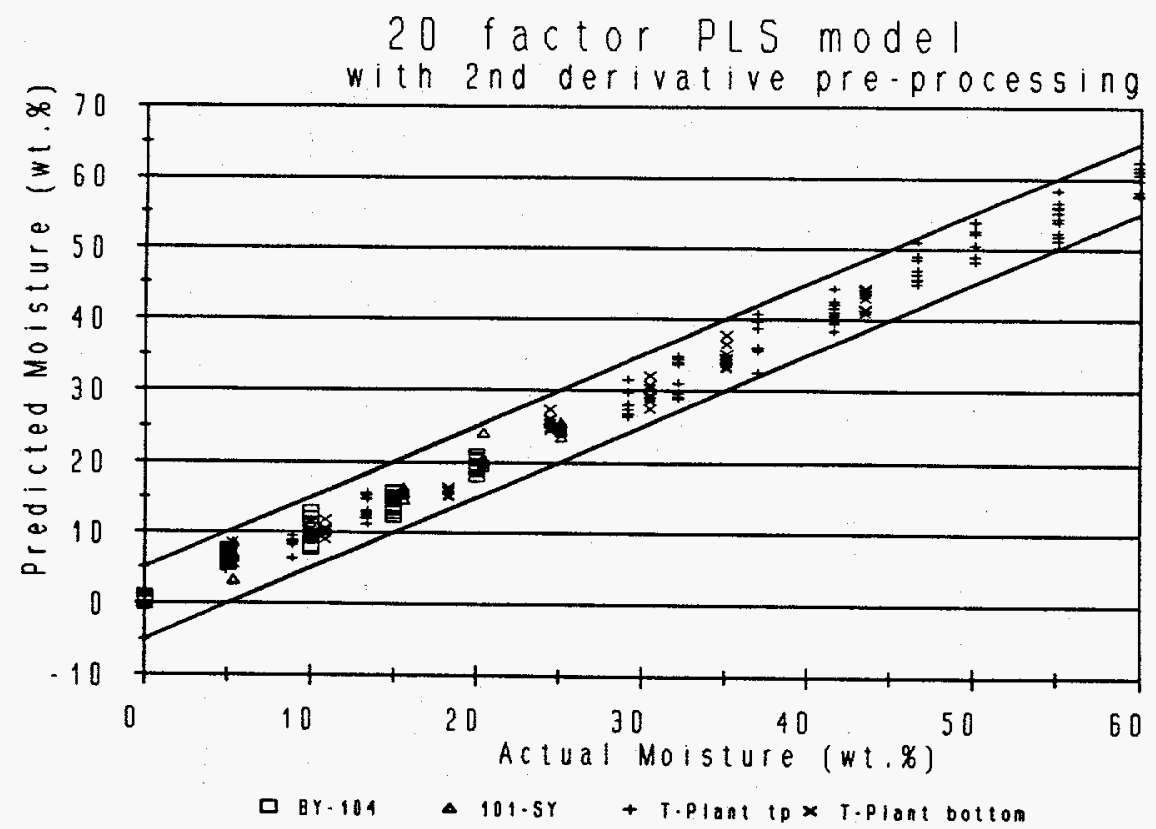

Figure 10. Twenty-Factor Partial-Least-Squares Model with Second Derivative Preprocessing.

PLS Model Performance

Total Moisture prediction Error and

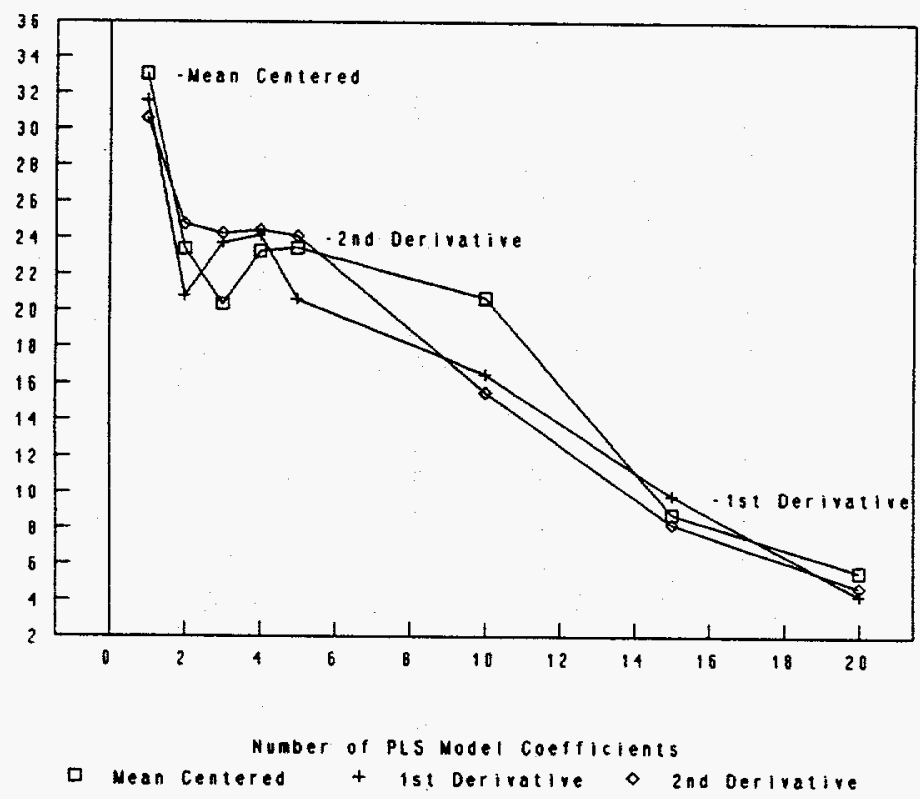

Figure 11a. Root-Mean-Square Error of Moisture Prediction of all Tank Simulants for Partial-Least-Squares Model Data in Table 3. 
PLS Model Performance

RMSEE of Moisture Prediction

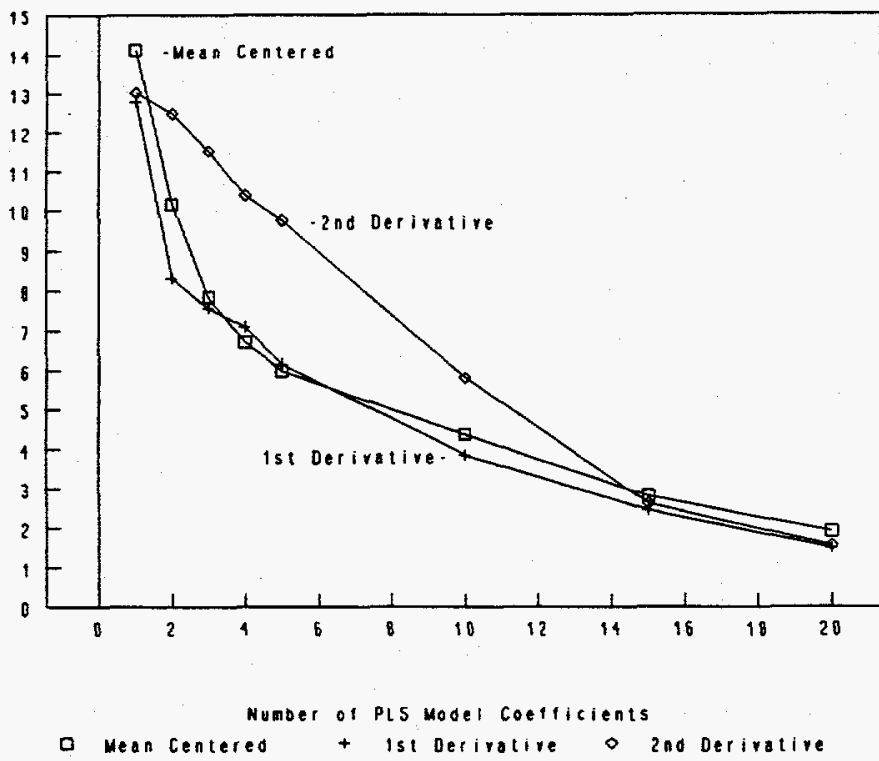

Figure 11b. 100 Percent Moisture Prediction Error Band for Partial-Least-Squares Models with all Tank Simulants.

\subsection{UNKNOWN SAMPLE PERFORMANCE SIMULATION}

To provide some indication of performance with "unknown" samples. calibration models were constructed leaving out selected simulant data sets. After the model was constructed. the omitted data sets were then used as "unknowns" to evaluate the performance of the calibration model. These provide some indication of the moisture sensing performance with materials and moisture levels that were not part of the calibration set.

Two types of "unknown sample" testing were completed:

- Moisture Sample Omission - Modeling without a selected moisture sample

- Tank Simulant Omission - Modeling without a selected tank sample.

\subsubsection{Moisture Sample Omission Tests}

Three separate moisture omission tests were completed:

- 10-wt\% moisture in BY-104

- 30-wt\% moisture in T Plant Bottom

- 50- to 60-wt\% moisture in T Plant Top.

These tests used a 20-factor PLS model with smoothed spectral data and second derivative preprocessing. In each test. the PLS model was constructed with all simulant data except for a specific moisture sample. The results of the model testing are shown in Figures 12. 13. and 14.

- 10-wt\% Moisture BY-104 - In this test. a calibration model was constructed using a11 simulant samples, including BY-104 samples, except the BY-104 sample with 10-wt\% moisture content. Figure 12 shows that 
this model then predicted the moisture content very well. with the predicted level falling within the \pm 5 wt\% boundary lines.

- 30-wtz Moisture in T Plant Bottom - In this test, a calibration model was constructed with all simulant samples, including the T Plant bottom samples, except the T Plant bottom 30-wt\% moisture sample. Figure 13 shows the model prediction for 30 -wt\% level at the -5 wt\% boundary line. This performance is acceptable. as the accuracy is still within a \pm 10 wt\% limit.

- 50- to 60-wty Moisture in T Plant Top - In this test, the 50-through 60-wt\% moisture T Plant top samples were omitted and a calibration model constructed with all other sample data. including other T Plant top moisture levels. The moisture levels predicted for the 50- and 60-wt\% samples are shown in the lower graph of Figure 14 . In this case. the model severely underpredicted the moisture content of the "unknown" samples. In addition, the precision of the model is not very good. as shown by the large scatter of the 50 - and 60 -wt\% predicted points. These tests indicate that a calibration model must include the whole range of moisture levels over which it is anticipated to operate.

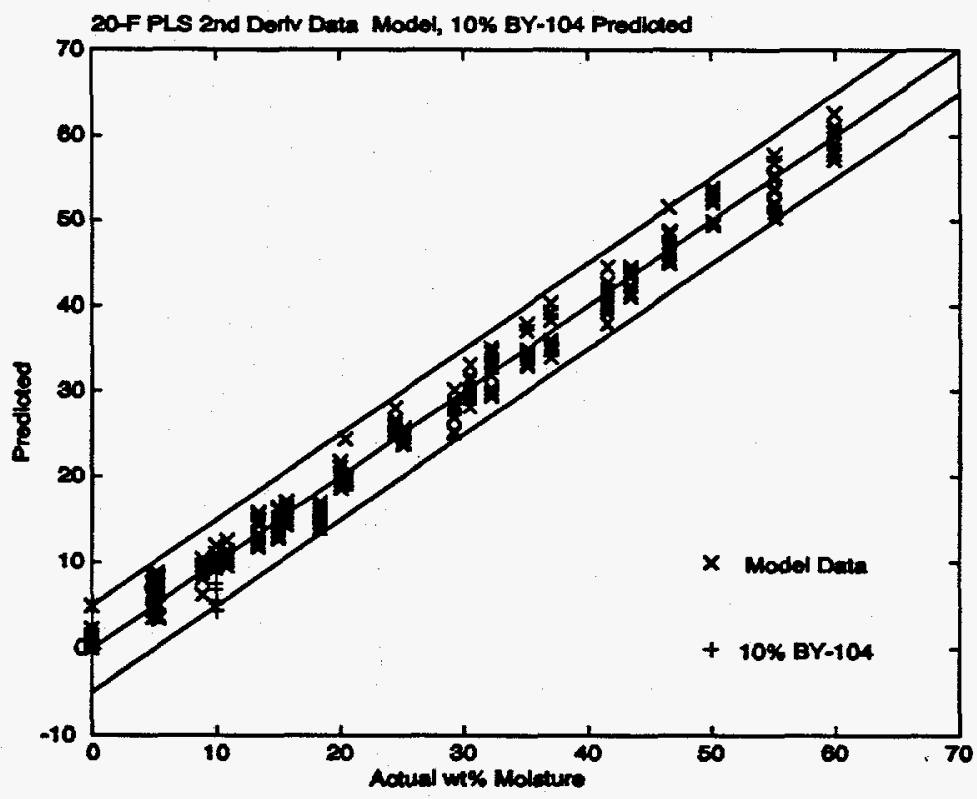

Figure 12. Partial-Least-Squares Model Predicting Moisture of the BY-104 10-wt\% Sample.

\subsubsection{Tank Simulant Omission Tests}

Two separate material tests were completed.

1. T Plant Bottom - In this test all T Plant bottom simulant moisture samples were omitted from the calibration. The performance of the model for the T Plant bottom samples is shown in Figure 15. Only the 9-and $35-w t \%$ samples fall within the \pm 5 wt\% boundary. The 18.3-. 25-. 35-. and 44-wt\% predictions have a larger error. but fail within a \pm 20 to 22 -wt\% boundary. It is conjectured that the model response was due to the 


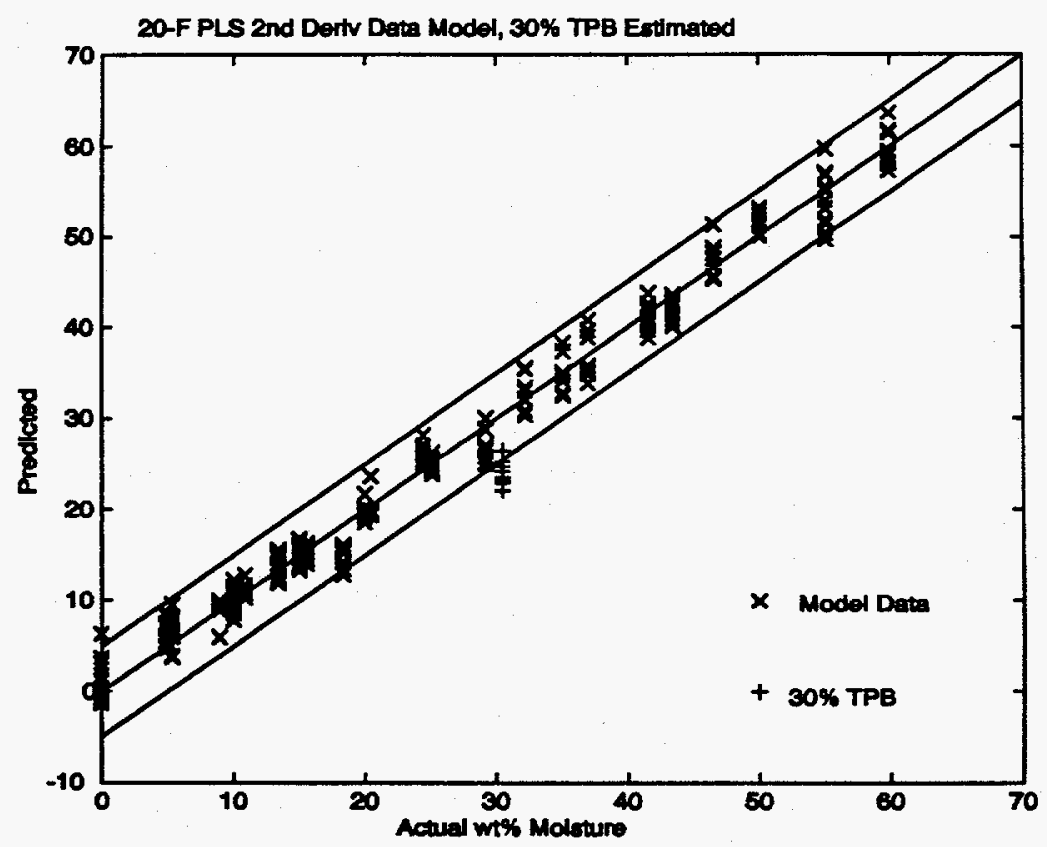

Figure 13. Partial-Least-Squares Model Predicting Moisture of the T Plant Bottom 30-wt\% Sample.

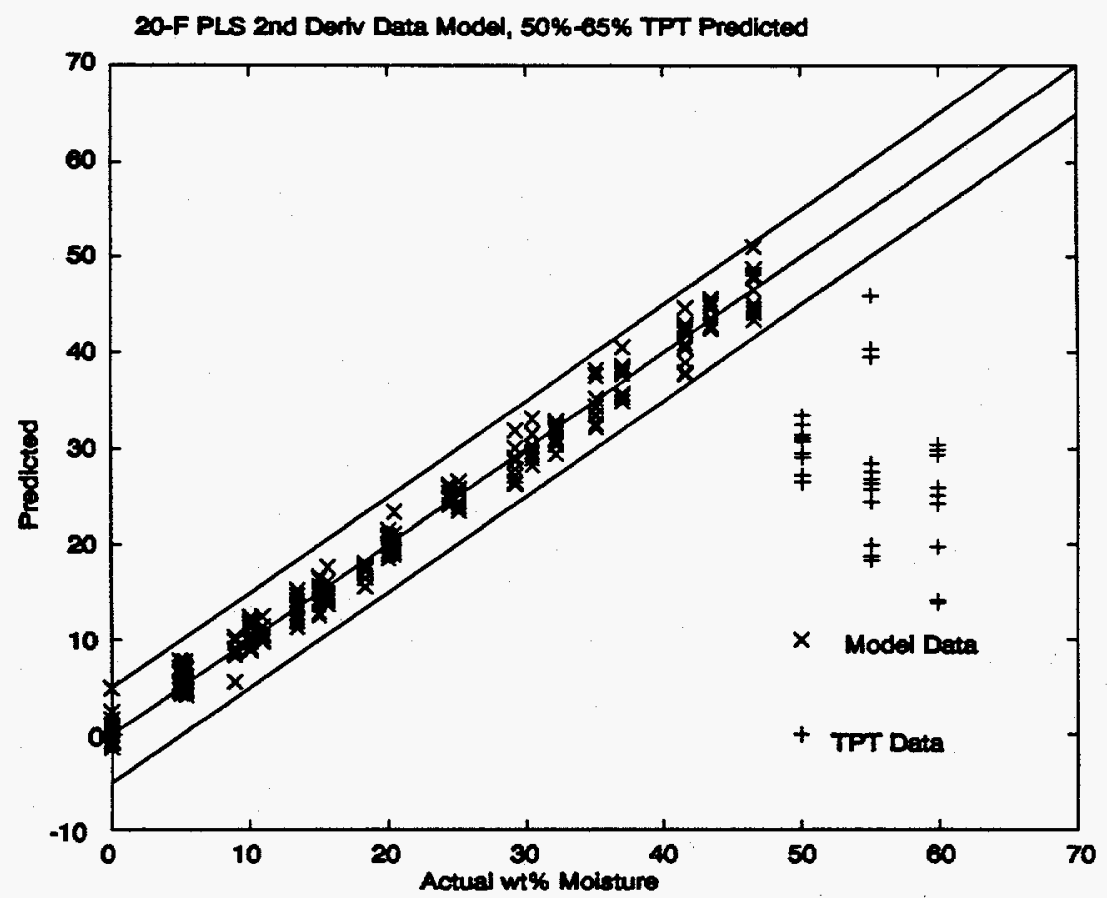

Figure 14. Partial-Least-Squares Model Predicting 50 - to 65-wt\% T Plant Top Samples.

inclusion of the T Plant top samples in the modeling. T Plant top shares many of the chemicals that are found in the T Plant bottom samples (see Appendix $B$ for a chemical listing). 
2. 101-SY - In this test. all 101-SY simulant data were omitted from the calibration model and used as unknowns to test the model. The results are shown in Figure 16. In this case the model's performance is rather poor with sample errors as large as 30 wt\% (25-wt\% sample). The 101-SY material simulates tank waste with an organic component

(hydroxyethylethylenediaminetriacetic acid [HEDTA]. as shown in Appendix B). The disparity of the chemical compositions is the major reason for the model's poor performance.

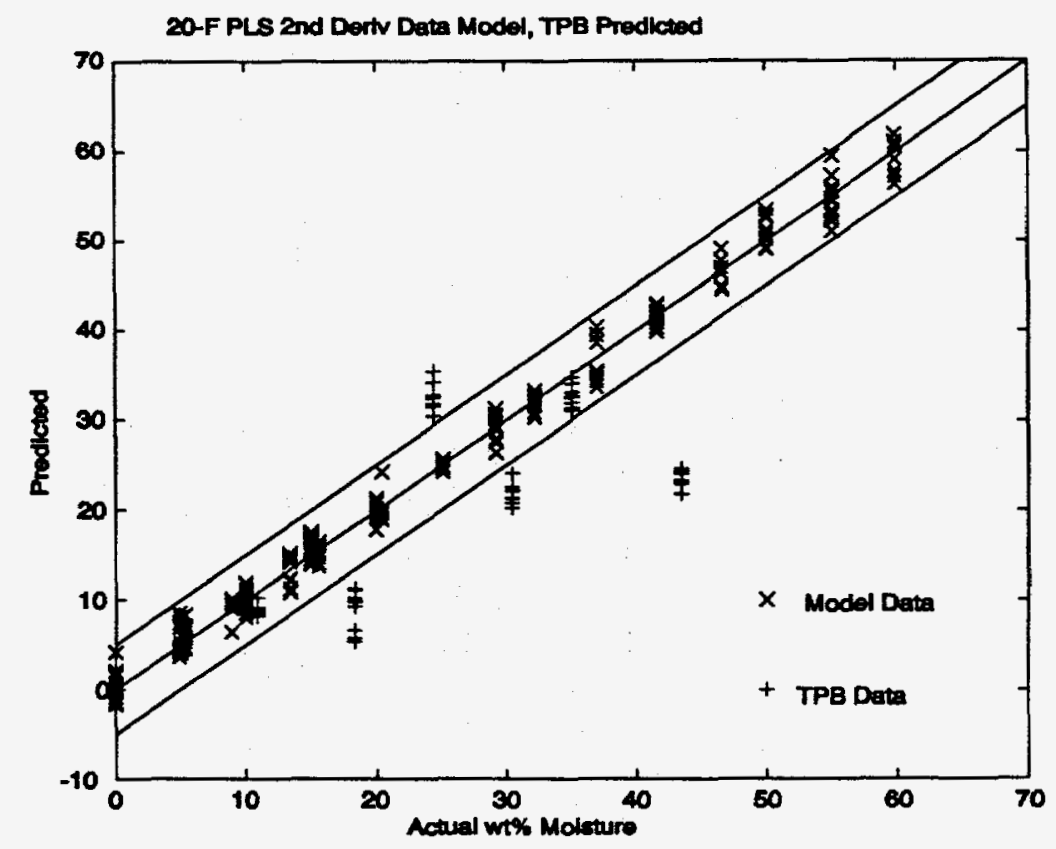

Figure 15. Twenty-Factor Partial-Least-Squares, Second Derivative Model Predicting all T Plant Bottom Samples (5-. 11-. 18.3-. 25-. 30-. 35-. 43.5-wt\% Moisture).

These tests indicate that a calibration model must include the whole range of major chemical constituents. especially organics with absorption bands near the water absorption band. in order to achieve the target waste tank material moisture prediction accuracy.

\subsection{SUMMARY AND CONCLUSIONS}

An NIR spectroscopy system, developed by SRL for hot cell applications, has been successfully tested and demonstrated with tank simulant materials for remote moisture measurement applications. These cold test/demonstrations show that the NIR spectroscopy moisture sensing technology is viable with tank waste types of materials that have a high caustic level and a variable molecular content. Further testing with real tank waste material is needed to verify that the technique is transferable to real tank materials.

The NIR spectral data were obtained with an SRL NIR spectroscopy system over a range of 1150-1675 $\mathrm{nm}$ and processed with offline software to construct and evaluate PLS-based calibration models. The spectral data were derived from backscattered optical energy that included the 1400-nm NIR water overtone absorption band. 


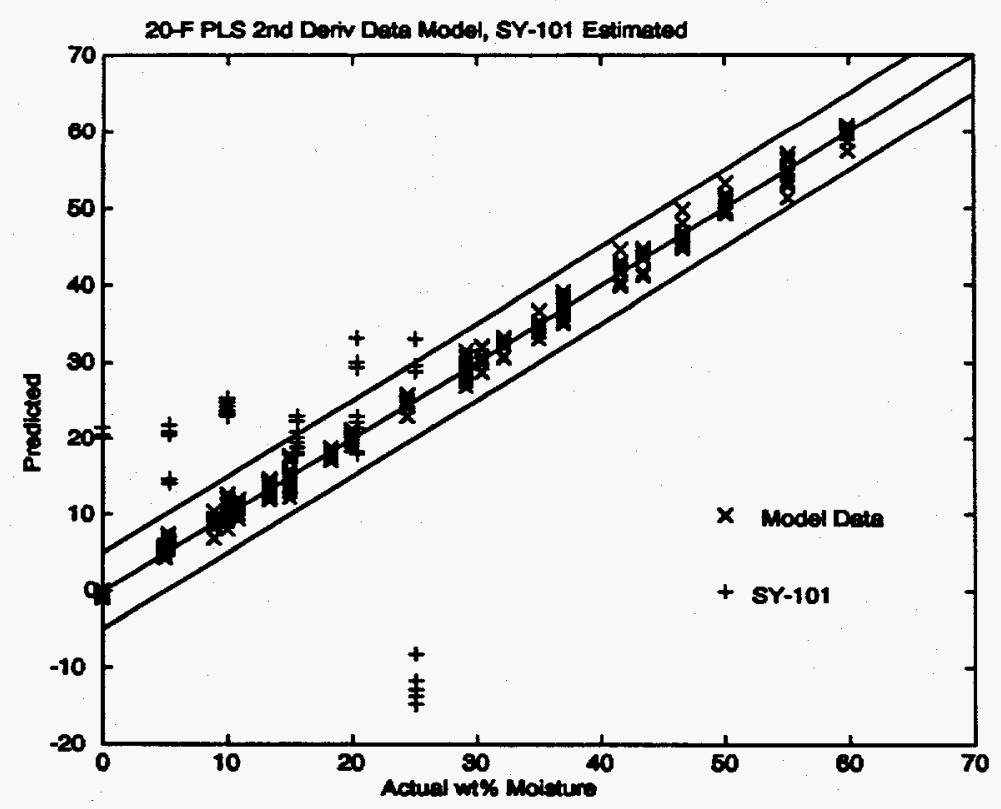

Figure 16. Twenty-Factor Partial-Least-Squares. Second Derivative Model Predicting al1 101-SY Samples (5-, 10-, 15-. 20-. 25-wt\% Moisture).

The results of this testing with moisture standards indicated a capability to sense moisture with an RMSE of less than \pm 2 wt\% over a moisture range of 0 to 60 wt\%. Over this same moisture range. the error for all predicted moisture levels from all samples fell within a \pm 5 wt\% error range (total error band). These results successfully meet the requirements needed to quantify the moisture in ferrocyanideand organics-bearing tank waste materials.

This moisture prediction performance was achieved using moisture standards prepared from a collective group of tank simulants that is representative of saltcake and slurry material from ferrocyanide and organic tanks (BY-104. T Plant top. T Plant bottom. and 101-SY simulants). The moisture prediction results were from calibration models built from several tested models.

The results of this testing are as follows.

- Multiple-coefficient. PLS-based calibration models provided a better moisture prediction performance than PCR-based models.

- Multiple-coefficient calibration models composed with first and second derivative preprocessing provided better moisture prediction than models developed with no or just mean-centering preprocessing of the spectra.

- The more chemically similar an unknown sample is to the chemistry of the samples used to make the calibration model. the better the model predicts the unknown samples' moisture content.

- The standards used to construct the calibration models must include the whole range of moisture levels over which the model will be used.

The following issues and further work need to be addressed by this project: 
1. A hot cell test campaign with real waste tank materials is needed to validate the NIR moisture response and the potential for using cold calibration models with major tank material chemicals.

- Cold test/analysis with NIR and Raman systems has shown that there are significant chemical and physical differences between simulant and real waste materials. The impact on moisture sensing is not known at this time.

2. The SRL NIR system hardware as it currently exists is not suitable for routine hot cell core scanning applications. This is not a basic technology issue, but a systems engineering issue. The existing system hardware would be usable in a hot cell demonstration to acquire data that could be processed with offline software when "real-time" moisture data is not needed. For onl ine data acquisition. improvements needed include

- System resident software that can handle the large number of calibration samples that will be required for more routine hot cell use

- Software testing to identify potential unresolved errors that are still part of the SRL system/hardware.

3. Cold testing is needed to verify the performance of a commercial NIR system purchased in FY 1994 as a replacement for the SRL systems.

- Calibration model software needs to be developed and integrated into the NIR moisture sensing system. The software needs to handle the large calibration data set. provide "real-time" moisture readout. and include multiple calibration programs to extract the "best" estimate of moisture from a tank sample.

- Total moisture sensing system packaging is needed that can handle the hot cell environment and current mode of system operation around a hot cel1.

4. Additional development work is needed for routine hot cell moisture sensing systems.

- A method for probe cleaning, or disposable probe sheaths, and light shielding need to be identified and tested relative to the use of the fiber optic probe in a hot cell application.

- A commercial source of fiber optic probes needs to identified. Handling and materials testing are needed to ensure probe integrity with the chemical mixtures that will be encountered in tank materials and to ensure that the replacement epoxy and new method of window attachment will not fail during hot cell use. 


\subsection{REFERENCES}

Hanion. B. M. . 1994. Tank Farm Surveillance and Waste Status Summary Report. WHC-EP-0182-74. Westinghouse Hanford Company. Richland. Washington.

Martens. H. and T. NæS. 1989. Multivariate Calibration. John Wiley \& Sons. New York. New York.

Merier. P. C.. and R. E. Zund, 1993. Statistical Methods in Analytical Chemistry. John Wiley \& Sons. Inc. New York. New York.

Postma. A. K.. J. E. Meacham. G. S. Barney. G. L. Borsheim. R. J. Cash. M. D. Crippen. J. M. Grigsby. D. W. Jeppson. M. Kummerer. J. M. McLaren. C. S. Simmons. B. C. Simpson. 1994. Ferrocyanide Safety Program: Safety Criteria for Ferrocyanide Watch List Tanks, WHC-EP-0691. Westinghouse Hanford Company. Richland. Washington.

Veltkamp. D. J., 1993. CPAC Moisture Study: Phase I Report on the Study of Optical Spectra Calibration for Moisture. WHC-SD-WM-ER-288. Rev. 0. Westinghouse Hanford Company. Richland. Washington.

Veltkamp. D. J.. 1994a. CPAC Optical Moisture Monitoring: Characterization of Composition and Physical Effects on Moisture Determination Task 2A Report. WHCSD-WM-ER-397. Rev. 0, Westinghouse Hanford Company, Richland, Washington.

Veltkamp. D. J., 1994b. Effect of Atmospheric Humidity on Center for Process Analytical Chemistry Optical Moisture Prediction Models - Interim Report. WHC-SD-WM-ER-386, Westinghouse Hanford Company. Richland. Washington. 
WHC-EP-0839

This page intentionally left blank. 
WHC-EP-0839

APPENDIX A

FERROCYANIDE AND ORGANIC TANKS

MOISTURE MEASUREMENT CRITERIA 
WHC-EP-0839

This page intentionally left blank. 


\section{MOISTURE MEASUREMENT REQUIREMENTS}

1. System deployed in the field must measure the tank waste moisture content over a range of 5 to 60 percent or more by weight.

2. Measurement accuracy must be plus or minus 5 percent moisture by weight in the 5 to 30 percent range and plus or minus 10 percent in the 30 to 70 percent range. The indicated moisture at 20 percent means the actual is between 15 and 25 percent for a system just meeting this requirement. The higher the indicated moisture, the less accuracy is necessary. The reduced accuracy is still needed at the higher concentrations because trending will be necessary to ensure decreasing moisture content will be detected.

3. Frequency of measurements should be assumed to be twice per year initially. If decreasing moisture occurs, the frequency would be assumed to increase.

\section{IMPORTANT CONSIDERATIONS FOR MEASUREMENT CONCEPTS}

The following concepts must be considered:

1. Deployment requirements (i.e.. direct contact with waste or indirect. such as through liquid observation wells [LOWs] or cone penetrometers)

2. Deployment through a $10-\mathrm{cm}-(4-$ in.-) diameter riser (there are essentially no larger risers available)

3. Sensitivity to chemical constituents and their distribution

4. Relative cost of installation

5. Relative development cost of obtaining required range and accuracy

6. Sensitivity to density of tank contents

7. Radius of investigation (response to moisture and material away from the probe and the distance involved)

8. Complexity and cost of above ground measurement system

9. Ease of installing. using, and maintaining system

10. Calibration requirements and the need for a calibration facility

11. Ease of interpreting data (trained technician should be able to interpret data)

12. Time required to obtain data (should be obtained from each tank in less than half hour)

13. Resistance of equipment to radiation

14. Suitability of equipment for field use (must be rugged) 
Systems that penetrate deeper into the waste may provide measurements more representative of the waste. Existing liquid observation wells (LOWs) are known to have substantial air gaps around them. Surface effects of a deployment system (cone penetrometer or new LOW) may cause a bias in the moisture concentration.

Measurement systems penetrating only a few centimeters may be influenced by the "cold finger" effect of a cooler metal surface. 
WHC-EP-0839

\section{APPENDIX B}

COMPOSITION OF TANK WASTE SIMULANTS 


\section{WHC-EP-0839}

This page intentionally left blank. 


\section{COMPOSITION OF TANK WASTE SIMULANTS}

BY-104 Saltcake Simulant.

\begin{tabular}{|l|c|c|c|}
\hline \multicolumn{1}{|c|}{ Compound } & CAS \# & Formula & Weight (\%) \\
\hline Sodium nitrate & $7631-99-4$ & $\mathrm{NaNO}_{3}$ & 81.8 \\
\hline Sodium aluminate & $11138-49-1$ & $\mathrm{NaAlO}_{2}$ & 7.5 \\
\hline Sodium hydroxide & $1310-73-2$ & $\mathrm{NaOH}$ & 1.7 \\
\hline Sodium metasilicate & $6834-92-0$ & $\mathrm{Na}_{2} \mathrm{SiO}_{3}$ & 1.5 \\
\hline Ferric nitrate & $10421-48-4$ & $\mathrm{Fe}\left(\mathrm{NO}_{3}\right)_{3}$ & 1.0 \\
\hline Sodium phosphate & $7601-54-9$ & $\mathrm{Na}_{3} \mathrm{PO}_{4}$ & 0.7 \\
\hline Calcium nitrate & $13477-34-4$ & $\mathrm{CaNaOH}_{3}$ & 0.4 \\
\hline Magnesium nitrate & $13446-18-9$ & ${\mathrm{Mg}\left(\mathrm{NO}_{3}\right)_{2}}_{2}$ & 0.2 \\
\hline Manganese (II) nitrate & $10377-66-9$ & ${\mathrm{Mn}\left(\mathrm{NO}_{3}\right)_{2}}_{2}$ & 0.2 \\
\hline Water & $7732-18-5$ & $\mathrm{H}_{2} \mathrm{O}_{2}$ & $\sim 5$ \\
\hline
\end{tabular}

*Amount of water in initial simulant before drying. 
Composition of T Plant Top Fraction.

\begin{tabular}{|l|c|c|c|c|c|}
\hline \multicolumn{1}{|c|}{ Compound } & Molarity & $\begin{array}{c}\text { Molecular } \\
\text { weight }\end{array}$ & $\omega t \%$ & $g / L$ & MSDS \\
\hline$\left(\mathrm{NH}_{4}\right)_{2} \mathrm{SiF}_{6}$ & 0.716834 & 178.1525 & 9.439 & 127.71 & 4491 \\
\hline $\mathrm{NaNO}_{3}$ & 1.137828 & 84.99467 & 7.148 & 96.71 & 1506 \\
\hline $\mathrm{Na}_{3} \mathrm{PO}_{4}$ & 0.54834 & 163.9407 & 6.644 & 89.90 & 1509 \\
\hline $\mathrm{Fe}(\mathrm{OH})_{3}\left(\mathrm{Fe}_{2} \mathrm{O}_{3}\right)$ & 0.620175 & 106.8689 & 4.899 & 66.28 & 1666 \\
\hline $\left.\mathrm{Na}_{2} \mathrm{NiFe} \mathrm{CN}\right)_{6}$ & 0.115838 & 303.9123 & 2.602 & 35.20 & 5793 \\
\hline $\mathrm{NaNO}_{2}$ & 0.433967 & 68.99527 & 2.213 & 29.94 & 1495 \\
\hline $\mathrm{Cr}\left(\mathrm{NO}_{3}\right)_{3}$ & 0.082279 & 238.0107 & 1.447 & 19.58 & 1132 \\
\hline $\mathrm{Na}_{2} \mathrm{SO}_{4}$ & 0.060255 & 142.0371 & 0.633 & 8.56 & 1621 \\
\hline $\mathrm{BiPO}_{4}$ & 0.024084 & 303.9518 & 0.541 & 7.32 & -- \\
\hline $\mathrm{Zr}_{3}\left(\mathrm{PO}_{4}\right)_{4}$ & 0.001533 & 653.5454 & 0.074 & 1.00 & 6865 \\
\hline $\mathrm{CsNO}_{3}$ & 0.003156 & 194.9103 & 0.045 & 0.62 & 2331 \\
\hline $\mathrm{H}_{2} \mathrm{O}$ (bound) & -- & 18.0152 & 1.240 & -- & -- \\
\hline $\mathrm{H}_{2} \mathrm{O}$ (free) & -- & 18.0152 & 69.000 & -- & -- \\
\hline
\end{tabular}

Amount of water in simulant before drying.

MSDS = Material safety data sheet. 
Composition of T Plant Bottom.

\begin{tabular}{|l|c|c|c|c|c|}
\hline \multicolumn{1}{|c|}{ Compound } & Molarity & $\begin{array}{c}\text { Molecular } \\
\text { weight }\end{array}$ & Wt\% & $g / L$ & MSDS \\
\hline $\mathrm{BiPO}_{4}$ & 1.388735 & 303.9518 & 31.198 & 422.11 & $-\cdot$ \\
\hline$\left(\mathrm{NH}_{4}\right)_{2} \mathrm{SiF}_{6}$ & 0.397438 & 178.1525 & 5.233 & 70.80 & 4491 \\
\hline $\mathrm{NaNO}_{3}$ & 0.399952 & 84.99467 & 2.512 & 33.99 & 1506 \\
\hline $\mathrm{Fe}(\mathrm{OH})_{3}$ & 0.269103 & 106.8689 & 2.126 & 28.76 & 1666 \\
\hline $\mathrm{Na}_{2} \mathrm{NiFe}(\mathrm{CN})_{6}$ & 0.037367 & 303.9123 & 0.839 & 11.36 & 5793 \\
\hline $\mathrm{NaNO}_{2}$ & 0.158517 & 68.99527 & 0.808 & 10.94 & 1495 \\
\hline $\mathrm{Cr}_{2}\left(\mathrm{NO}_{3}\right)_{3}$ & 0.041504 & 238.0107 & 0.730 & 9.88 & 1132 \\
\hline $\mathrm{Na}_{2} \mathrm{SO}_{4}$ & 0.025564 & 142.0371 & 0.268 & 3.63 & 1621 \\
\hline $\mathrm{Zr}_{3}\left(\mathrm{PO}_{4}\right)_{4}$ & 0.005439 & 653.5454 & 0.263 & 3.55 & 6865 \\
\hline $\mathrm{CsNO}_{3}$ & 0.0007 & 194.9103 & 0.010 & 0.14 & 2331 \\
\hline $\mathrm{H}_{2} \mathrm{O}$ (bound) & $-\cdot$ & 18.0152 & 0.550 & -- & $-\cdot$ \\
\hline $\mathrm{H}_{2} \mathrm{O}$ (free) & $-\cdot$ & 18.0152 & 45.000 & -- & $-\cdot$ \\
\hline
\end{tabular}

Amount of water in simulant before drying.

MSDS = master safety data sheet. 
Composition of 101-SY Simulant.

\begin{tabular}{|l|c|c|}
\hline \multicolumn{1}{|c|}{ Compound } & Wt\% & MSDS \\
\hline $\mathrm{NaNO}_{2}$ & 16.19 & 1506 \\
\hline $\mathrm{NaAlO}_{2}\left(2 \mathrm{H}_{2} \mathrm{O}\right)$ & 14.48 & 1020 \\
\hline $\mathrm{NaNO}_{3}$ & 13.41 & 1495 \\
\hline $\mathrm{NaOH}$ & 7.08 & 1105 \\
\hline $\mathrm{Na}_{2} \mathrm{CO}_{3}$ & 6.69 & 1484 \\
\hline $\mathrm{Na}_{4}{\mathrm{EDTA} 2 \mathrm{H}_{2} \mathrm{O}}_{3}$ & 5.45 & 2370 \\
\hline $\mathrm{Cr}\left(\mathrm{NO}_{3}\right)_{3} 9 \mathrm{H}_{2} \mathrm{O}$ & 3.24 & 1132 \\
\hline $\mathrm{Na}_{3} \mathrm{PO}_{4} 12 \mathrm{H}_{2} \mathrm{O}$ & 2.63 & 1509 \\
\hline $\mathrm{NaCl}^{2}$ & 1.34 & 1485 \\
\hline $\mathrm{KNO}_{3}$ & 0.87 & 1619 \\
\hline $\mathrm{Na}_{2} \mathrm{SO}_{4}$ & 0.61 & 1621 \\
\hline $\mathrm{Fe}\left(\mathrm{NO}_{3}\right)_{3} 9 \mathrm{H}_{2} \mathrm{O}$ & 0.21 & 1214 \\
\hline $\mathrm{Ca}\left(\mathrm{NO}_{3}\right)_{2} 4 \mathrm{H}_{2} \mathrm{O}$ & 0.14 & 1090 \\
\hline $\mathrm{Ni}\left(\mathrm{NO}_{3}\right)_{2} 6 \mathrm{H}_{2} \mathrm{O}$ & 0.08 & 1379 \\
\hline $\mathrm{NaF}$ & 0.068 & 1491 \\
\hline $\mathrm{ZnCl}$ & 0.0043 & 1866 \\
\hline $\mathrm{CsNO}$ & 0.0022 & 2331 \\
\hline $\mathrm{Sr}_{3}\left(\mathrm{NO}_{3}\right)_{2}$ & 0.00015 & 1523 \\
\hline $\mathrm{H}_{2} \mathrm{O}\left(\mathrm{free}^{*}\right.$ & 27.51 &.- \\
\hline
\end{tabular}

Amount of water in simulant before drying.

MSDS = master safety data sheet. 
WHC-EP-0839

\section{DISTRIBUTION}

\section{Number of Copies}

\section{OFFSITE}

6

U.S. Department of Enerqy. Headquarters 12800 Middlebrook Road Germantown, Maryland 20874
S. Gibson
K. Lange
C. Purdy
S. Wolfe

(3)

1

U.S. Department of Energy. Morgantown Energy Technology Center P.0. Box 880 3610 Collins Ferry Road

Morgantown, West Virginia 26507-0880

C. Nakaishi

1

U.S. Department of Energy. Savannah River Operations office P.0. Box A

Aiken, South Carolina 29808

T. Temple

1

U.S. Department of Energy.

Science Applications International Corporation 12850 Middlebrook Road

Trevion I, Suite 300

Germantown, Maryland 20874

R. Daniels

2

U.S. Department of Energy.

Science Applications International Corporation 2030 Century B1vd, Suite 200B

Germantown, Maryland 20874

H. Sutter

P. Szerszen 
WHC-EP-0839

DISTRIBUTION (cont.)

\section{Number of Copies}

\section{OFFSITE}

Tank Advisory Panel Members

C. S. Abrams

1987 Virginia

Idaho Fails, Idaho 83404

D. 0. Campbe 11

102 Windham Road

Oak Ridge, Tennessee $\mathbf{3 7 8 3 0}$

F. N. Carlson

6965 North 5 th West

Idaho Falls, Idaho 83401

D. T. Oakley

409 12th Street SW, Suite 310

Washington, D.C. 20024-2188

W. R. Prindle

1556 Crestline Drive

Santa Barbara, California 93105

A. Schneider

5005 Hidden Branches Drive

Dunwoody, Georgia 30338

1

Ames Laboratory

Room 106, Speeding Hall

Iowa State University

Ames, Iowa 50011-3058

P. Wang

Brookhaven National Laboratory Upton, New York 11973

K. Bandyopadhyay

Fauske and Associates. Inc. 16 W070 W. 83rd Street Burr Ridge, Illinois 60521

H. Fauske 
WHC-EP-0839

DISTRIBUTION (cont.)

Number of Copies

OFFSITE

1

Harvard University

295 Upland Avenue

Newton Highlands, Massachusetts 02161

M. First

3

Lawrence Livermore National Laboratory

P.0. Box 808

Livermore, California 94550

B. Hudson

K. Kyle

F. Milanovich

5

Los Alamos National Laboratory

P.0. Box 1663

Los Alamos, New Mexico 87545

S. Agnew

R.J. Donohoe

INC-14, MS C345

S. W. Eisenhawer

T. Larson

L. H. Sullivan

MS-P915, DX-DO

3

Oak Ridge National Laboratory

P.0. Box 2008

Oak Ridge, Tennessee 37831

E. Collins

C. Forsberg

7930, MS-6385

T. Kress

MS-6495

9108, MS-8088

1

Rice University

5211 Paisley

Houston, Texas 77096

A. Veletsos

2

Sandia National Laboratory

P.0. Box 5800

Albuquerque, New Mexico 87815

D. Powers

6404, MS-0744

S. Slezak

6415, MS-0741

Distr-3 


\section{DISTRIBUTION (cont.)}

\section{Number of Copies}

\section{OFFSITE}

1

University of Idaho

Chemistry Department

Moscow, Idaho 83844-2343

P. Griffiths

1

University of South Carolina

Electrical and Computer Engineering

Swearingen Engineering Center

Columbia, South Carolina 29208

J. Byrd

1

University of Washington

Department of Chemistry, BG-10

131 Chemistry Library Bidg.

Seattle, Washington 98195

B. R. Kowalski

1

Vanderbilt University

P.0. Box 1596, Station B

Nashville, Tennessee $\mathbf{3 7 2 3 5}$

F. Parker

2

Westinghouse Savannah River Laboratory

P.0. Box 616

Aiken, South Carolina 29802

R. Livingston

P. O'Rourke

ONSITE

U.S. Department of Energy.

Richland Field office

D. A. Brown

K8-50

M. H. Campbell

$57-73$

R. F. Christensen

S7-54

J. M. Clark

S7-54

R. E. Gerton

S7-54

R. G. Harwood

S7-54

W. F. Hendrickson

$57-54$

T. Noble

$57-54$

D. E. Trader

K8-50 
WHC-EP-0839

DISTRIBUTION (cont.)

\section{Number of Copies}

ONSITE

1

Los Alamos National Laboratory

P.G. Eller

B1-40

1

Mactech

V. FitzPatrick

K8-50

9

Pacific Northwest Laboratory

S. A. Bryan

P7-25

S. D. Colson

K2-14

J. S. Hartman

R. L. Hockey

K5-25

P. K. Melethil

K5-25

R. D. Scheele

P7-22

G. F. Schiefelbein

P7-25

T. M. Sloane

P8-38

M. J. Quadrel

$\mathrm{K} 5-25$

K9-69

59

Westinghouse Hanford Company

R. Akita

T6-20

H. Babad

S7-30

R. A. Bechtold

J. D. Berger

D. C. Board

LO-18

LO-18

S1-57

G. L. Borsheim

H5-27

D. R. Bratzel

S7-31

R. J. Cash

S7-15

M. D. Crippen

D. A. Dodd

L5-31

J. G. Douglas

G. T. Dukelow

J. B. Duncan

S. J. Eberlein

T6-50

L5-55

S7-15

L5-55

S7-31

R. C. Eschenbaum

N1-21

G. D. Forehand

S7-31

J. C. Fulton

$\mathrm{X} 0-17$

R. L. Gilchrist

L5-63

J. M. Grigsby

S7-15

C. S. Homi

R2-12

M. N. Islam

R3-08

D. W. Jeppson

L5-31

J. R. Jewett

T6-09 
WHC-EP-0839

\section{DISTRIBUTION (cont.)}

\section{Number of Copies}

\section{ONSITE}

Westinghouse Hanford Company (cont.)

R. E. Johnson

L5-55

T. J. Kelley

S7-30

M. Kummerer

H4-62

L. L. Lockrem

S3-90

T. Lopez

L5-55

J. E. Meacham

S7-15

S. J. Mech

L5-55

C. T. Narquis

T6-16

M. A. Payne

S7-14

B. L. Philipp

L7-05

R. S. Popielarczyk

R1-30

A. K. Postma

H4-62

T. V. Rebagay

F. R. Reich (6)

T6-30

D. A. Reynolds

L5-55

G. L. Schutzenhofer

R2-11

J. P. Sederburg

L5-55

B.C. Simpson

R2-11

H. Toffer

R2-12

D. A. Turner

HO-38

W. T. Watson

S7-15

W. D. Winkelman

HO-38

P. A. Young

L5-55

W. F. Zuroff

S7-12

Central Files

(2)

R1-30

Document Processing and

L8-04

Distribution

L8-15

EDMC

OSTI

(2)

H6-08

Tank Farm Information Center

L8-07

RI-20 